\title{
Three Faience Rosette Discs in the Museo Egizio in Turin: \\ The Early Ramesside Pharaohs in the Eastern Delta, and Their Glittering Palaces
}

Virginia Webb

Three small faience rosette discs now in the Museo Egizio of Turin, one of which has a given provenance from Heliopolis, while another bears the inscription 'Tel el-Yahoudeh', form an intriguing introduction to a certain type of Egyptian palace architectural decoration. They also trace the sorry story of the pillage of Ramesside sites in the Delta. Not only was it possible for near contemporary Pharaonic activity to transport and relocate the majority of the stone monuments of a whole city (Qantir-Piramesses to Tanis), to the extreme puzzlement of Egyptologists, but the smallest elements of certain ritual buildings also proved irresistible, since for the sebakhin they were highly portable and saleable. The renewed commercial opportunities offered by European travellers in the nineteenth century sounded the death knell for buildings decorated with these attractive decorative elements. Here I shall take a detailed look at the rosette tiles, their possible sources, and the light they throw on techniques of faience manufacture.

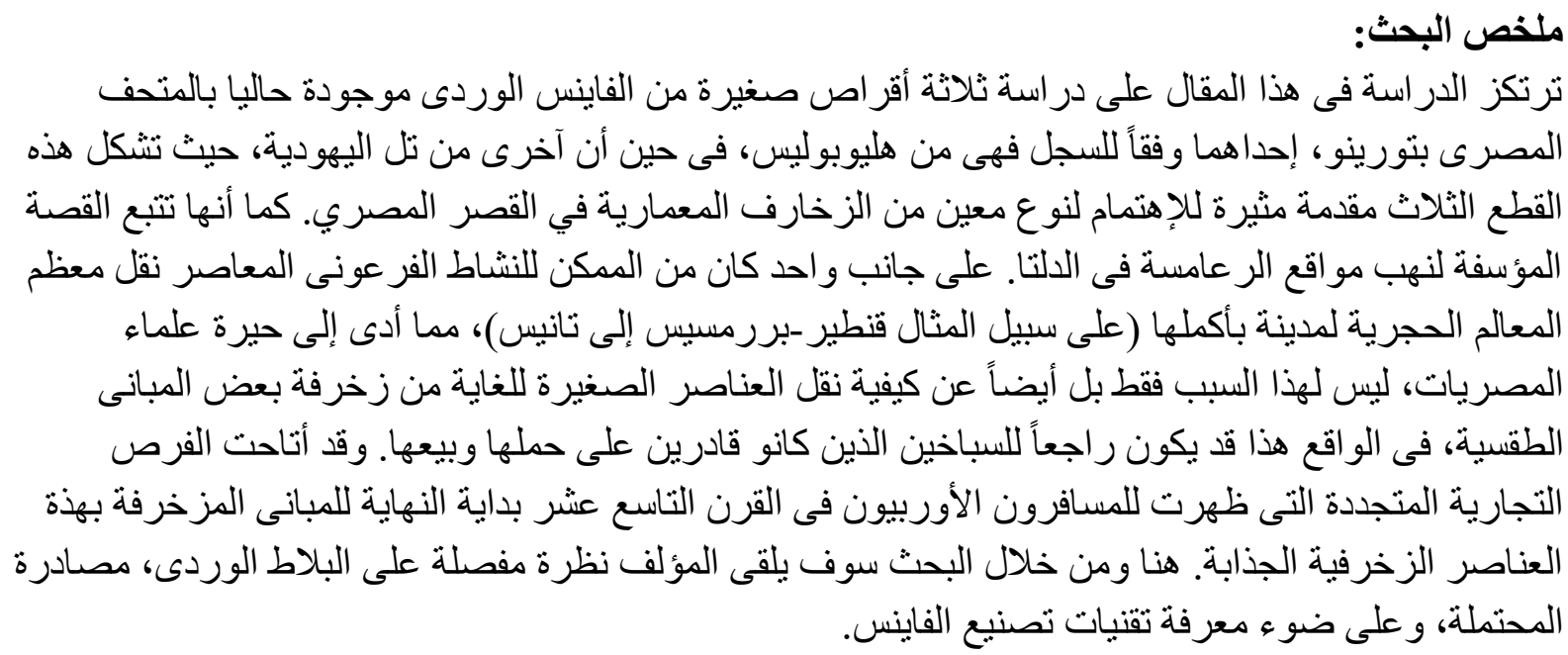

On voit continuellement des quantités d'hommes piocher ces décombres, tamiser ce qu'ils en retirent et transporter ce terreau à dos d'ânes et de chameaux à grandes distances, comme d'ailleurs cela se pratique partout où se trouvent les restes d'une ancienne ville égyptienne.

(Linant de Bellefonds, 1825)

Faience, tjehnet, which glittered like the sun, the moon and the stars and like precious materials such as lapis lazuli and turquoise, advertised to the Pha- raoh's enemies that he was invincible, and unforgiving. Faience was considered to have magical powers of transference - it was used for substitute models in burial contexts, and the solar symbolism of the rosettes, as well as the many tiles depicting the subjects of the Pharaoh in bondage, amplified the message. It is this material which was used to cover the entrances and inner surfaces of an unusual and striking form of architecture belonging to the early Ramesside pharaohs. In particular, the depictions of the traditional enemies of Egypt, known conventionally as the Nine Bows, formed a central 
part of the decoration, either shown bringing offerings, or bound as prisoners. The foundation of a new capital in the Eastern Delta by Ramesses II was, at least in part, a response to the threat from the Near Eastern powers, emphasized by the fact that the subject victims at the bottom of the stepped daises at Piramesses were invariably Asiatics, (and not the normally contrasted figure of the Nubian) being consumed by the Pharaoh's attendant lion. Three small faience rosette discs in the Museo Egizio in Turin form an intriguing introduction to this unusual and impressive phase of Egyptian Palace architectural decoration. We are all familiar with the artistic naturalism of the painted floors of Tell el-Amarna, and also with the many and varied tiles made in faience used in astonishing multiplicity to decorate the surfaces of columns, walls and floors in the Palaces of Akhenaten. ${ }^{2}$ But in the ambitious days of the early Ramesside pharaohs - Seti II, Ramesses II and III - palace decoration reached the extremes of ingenuity by using inlaid and over-glazed faience tiles to decorate and construct doorways, walls, columns, floors and throne daises. At Qantir, in addition, there were enormous sculptural figures of lions grasping Asiatic captives, set at the base of the dais steps to form newel posts. In the Eastern Delta at Tell el-Yahudiyeh and at Qantir (ancient Piramesses), and, as it now appears, at Heliopolis as well, and undoubtedly at Medinet Habu in Thebes, the pharaohs of the Ramesside period used faience tiles to make vivid assertions of their power in the decorations of their palaces. Other possible sites that contained such structures may include Elephantine. ${ }^{3}$

The tiles and human and animal figures are a striking illustration of the skill of the faience workers, and illustrate the use of a wide range of colour sources in glazing and inlay. ${ }^{4}$ They appear to have been mass-produced at an industrial scale; interestingly though, the rectangular tiles, architectural elements and sculptural groups bear decoration applied freehand..$^{5}$ By contrast, as a corollary to the production of these tiles and combined human and animal groups, there is one type of object which was produced in even greater numbers, and with apparently strict adherence to accuracy and exact replication. These are the circular tiles decorated with a rosette or, more precisely, a marguerite or daisy flower, ${ }^{6}$ or alternatively with a rhomboid-shaped diamond with miniature central rosette, which were commonly used in decorative borders in palace walls and floors, dadoes and other structures. Their design is a standard eight or ten-petal rosette with a central yellow knob and they derive from one type of rosette found at Tell el-Amarna. ${ }^{7}$ It is notable that this prototype with its flat petals and simple lay-out differs from the more naturalistic rosettes commonly employed in Akhenaten's palaces.

As attractive and portable objects they, and the more distinctive portrayals of subject races, were eagerly collected and sold on the antiquities market. The history of such dispersal is complex, and the process of dispersal and rediscovery of similar finds from Qantir can stand as an example. ${ }^{9}$ The rosettes from Tell el-Yahudiyeh appear in so many collections of Egyptian antiquities ${ }^{10}$ that it would be unhelpful to list them all, even if that were possible. They are often without the accompaniment of their larger and more immediately striking counterparts bearing human and animal depictions.

So it is that in the Museo Egizio, Turin, there are three rosette tiles which not only pose interesting questions about their ultimate origin, but also give insight into production techniques, and confirm the importance of the Eastern Delta to the Ramesside pharaohs.

\section{The three rosettes: fact sheets and descriptions}

\section{No. 1}

(Fig. 1)

Inventory number: Cat. $6824 .^{11}$

Dimensions: Diameter $3.5 \mathrm{~cm}, 0.5 \mathrm{~cm}$ thick.

Material: Light cream/off white petals on a dark grey background. In the middle is a raised knob in yellow. Description: The eight petals of almost equal size surround the central knob. The distance between their outer edges and the edge of the disc varies very slightly. The two colours on the face of the disc lie flush and show signs of inlay technique, namely, a separation line between the petals and the background colour. The back of the disc shows the same light cream glaze as the petals, and the darker glaze 
surrounding the petals is an inlaid coating which flows over the narrow outer edge and stops half way down. (See the section on Manufacturing Technique at the end of the article.) A raised knob of added faience material (in yellow) constitutes the centre of the flower. There is no central perforation.
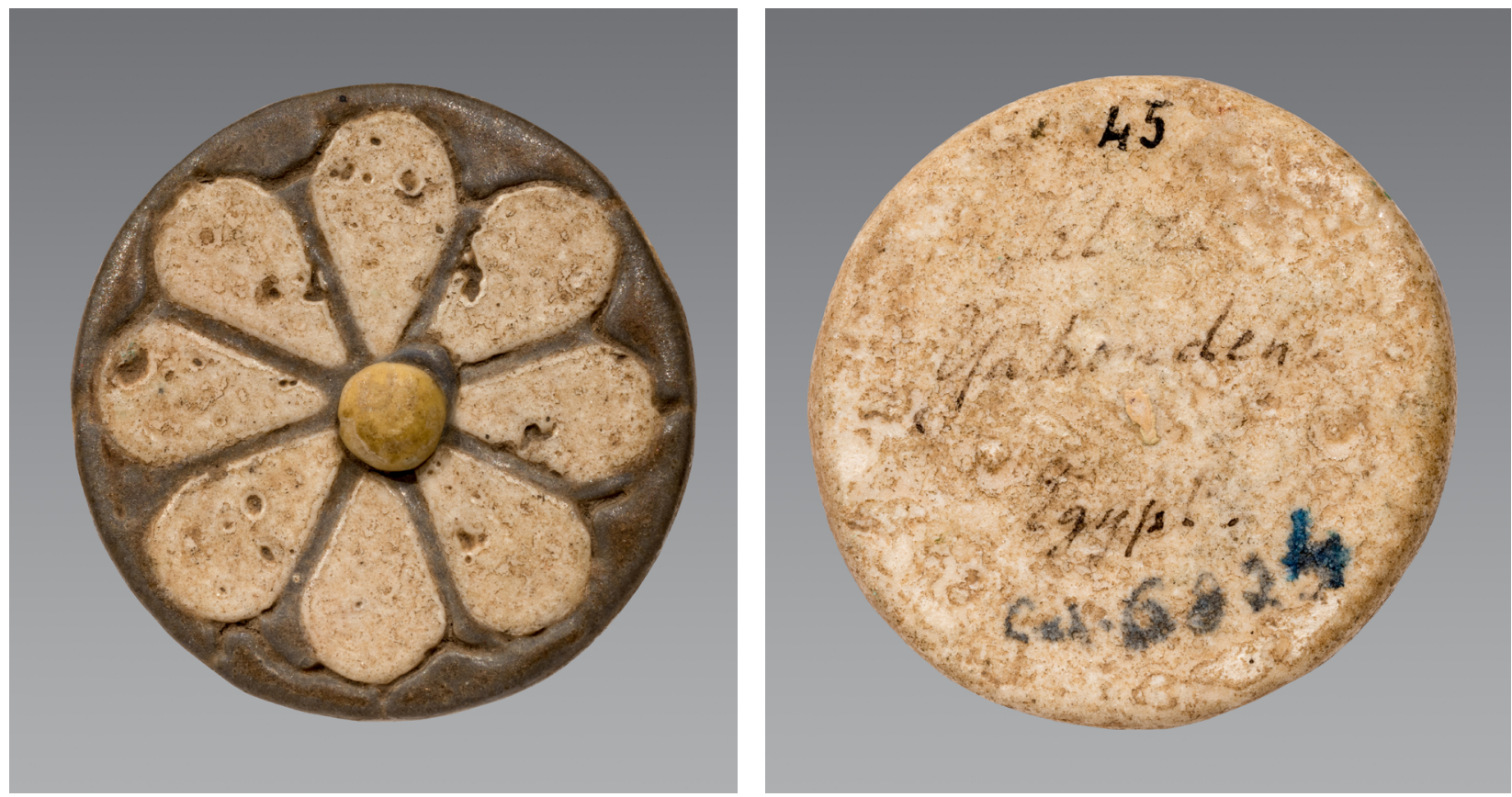

Fig. 1. Rosette disc Turin, Museo Egizio, Cat. 6824. Photo by Virginia Webb.

Provenance: Unknown.

Acquisition: It entered the collection of the Museo Egizio sometime between 1824 (when Bernadino Drovetti's collection reached the Museum) and 1888 - when Volume Two of the catalogue by Fabretti et al. was published. It is possible that it formed part of Drovetti's sale to the Museum, but recent (and much appreciated) research done by Beppe Moiso on my behalf into the concise list of the Drovetti collection drawn up by Carlo Vidua in 1822, before and preliminary to its purchase by the Turin Academy, failed to identify the two rosettes with Cat. nos. with any objects listed by Vidua. ${ }^{12}$ It is thus possible, although not certain, that they do not belong to the Drovetti collection. Many small lots of antiquities or individual objects entered the Museum as donations or purchases after the Drovetti collection was bought in 1824 and before the publication of Volume Two of the catalogue by Fabretti et al., but a search by Moiso into these was also unsuccessful. ${ }^{13} \mathrm{~A}$ short list of Egyptian objects donated by a Morpurgo in 1894-95 does include a 'margherita in porcellana', but the donation is too late for this object (as yet untraced) to have received a Cat. number (it actually bears a number 7211 from a lost inventory). ${ }^{14}$
Additional information: Although not mentioned in the entry in Fabretti et al.'s catalogue, there is an inscription on the back in black ink copper-plate handwriting:

\section{“Tel el Yahoudeh Egypt."}

This suggests that the piece has a history that might possibly be traced, and that it came to the Museum via another route. I shall discuss this below.

\section{No. 2}

(Fig. 2)

Inventory number: S. 2763.

Dimensions: Diameter $3.45 \mathrm{~cm}, 0.6 \mathrm{~cm}$ thick. Material: Light cream petals on a dark grey background. In the middle there would have been an added knob of pale yellow, as on No. 1 above (Turin Cat. 6824) but it has been worn down to the surface of the disc, or merely knocked off, and there is no central perforation.

Description: The eight petals of almost equal size surround the central knob, although the distance 
between their outer edges and the edge of the disc varies very slightly. The back of the disc shows the same light cream as the petals. The two colours on the face of the disc lie flush and show signs of inlay technique, i.e., a separation line along the division between the petals and the background colour. The back of the disc shows the same light cream glaze as the petals, and the darker glaze surrounding the petals is an inlaid coating which flows over the narrow outer edge and stops half way down. (See the section on Manufacturing Technique at the end of the article.)
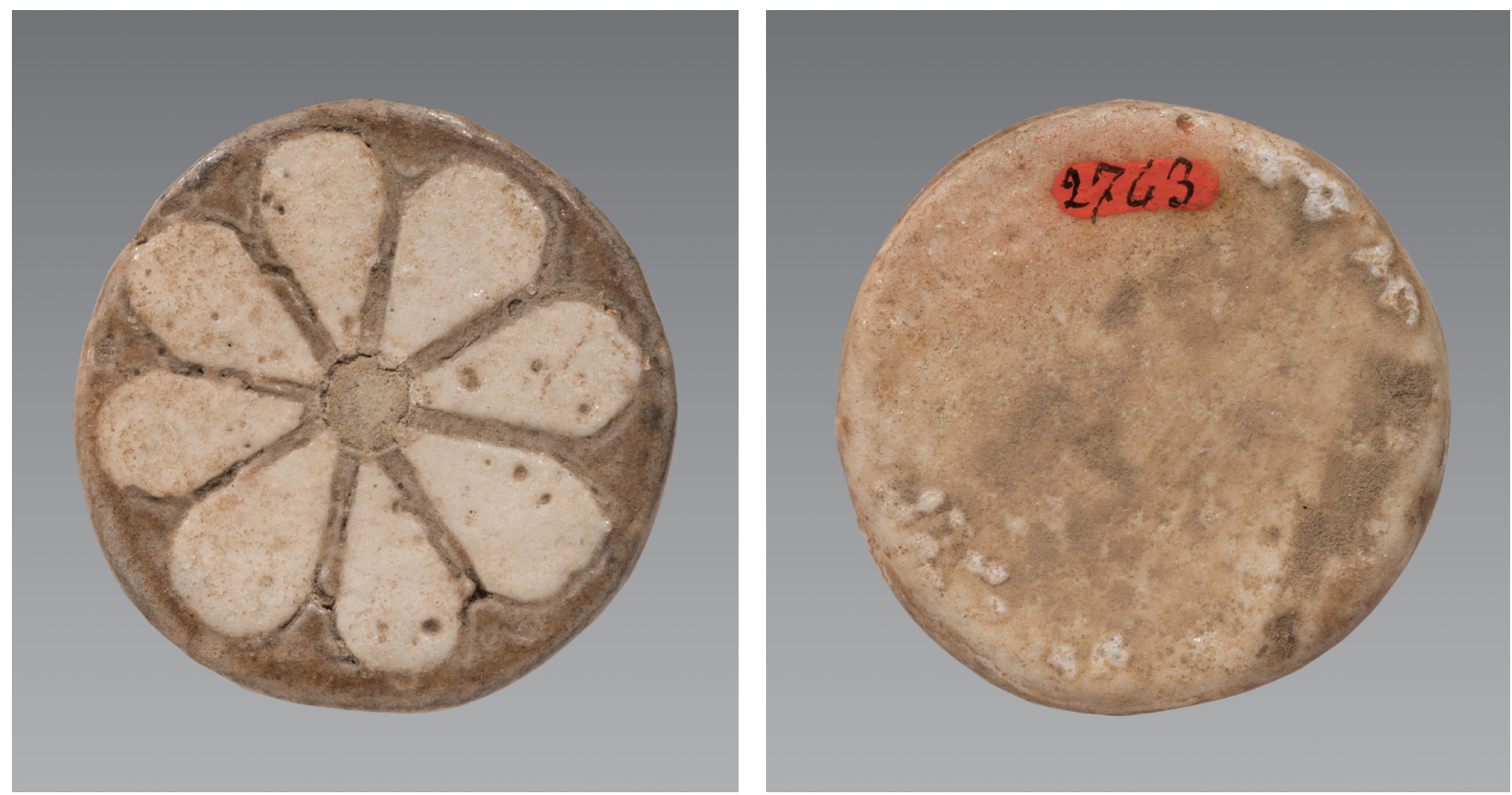

Fig. 2. Rosette disc Turin, Museo Egizio, S. 2763. Photo by Virginia Webb.

Provenance/Acquisition: Acquired from the partition of finds from Ernesto Schiaparelli's excavations at Heliopolis in 1903 or 1906. In Schiaparelli's Find List, it is among the objects found in the "Scavi del tempio". According to Federica Ugliano, who is researching Schiaparelli's records of his excavations,

it comes from the excavations that

Schiaparelli carried out in 1903 in one of the two trenches that he excavated in the temple area, 100 m east of the Senusret obelisk [see plan attached, Fig. 6] or from the excavations done in the same area in $1904 .{ }^{15}$

Tiles Nos. 1 and 2 (listed above) are identical in size and colouring, and definitely appear to be products of the same factory. It is therefore a question to be addressed whether there is a mistake in the provenances given. More on this later!

Thirdly, a different design, though clearly a similar object:

\section{No. 3}

(Fig. 3)

Inventory number: Cat. $7385 .{ }^{16}$

Dimensions: Diameter $4.3 \mathrm{~cm}, 0.8 \mathrm{~cm}$ thick.

Material: Dark blue petals on a lighter blue background.

Description: The ten petals of varying size and coloured dark blue against a light blue background radiate from a notional centre, which is actually occupied by a large perforation. The petal material is inserted into previously moulded or cut-out cells made in the main body of the rosette. (This manufacturing method is a simpler version of that used on the other two examples above as here it lacks the additional colouring material inlaid around the outline of the petals, and the smooth flush finish overall, which is typical of the Tell el-Yahudiyeh discs.) Centrally pierced with a distinct hole, the back is slightly convex, with a coarse bubbled surface - the remains of a poorly surviving blue glaze - possibly evidence of the use of the effervescence technique. 

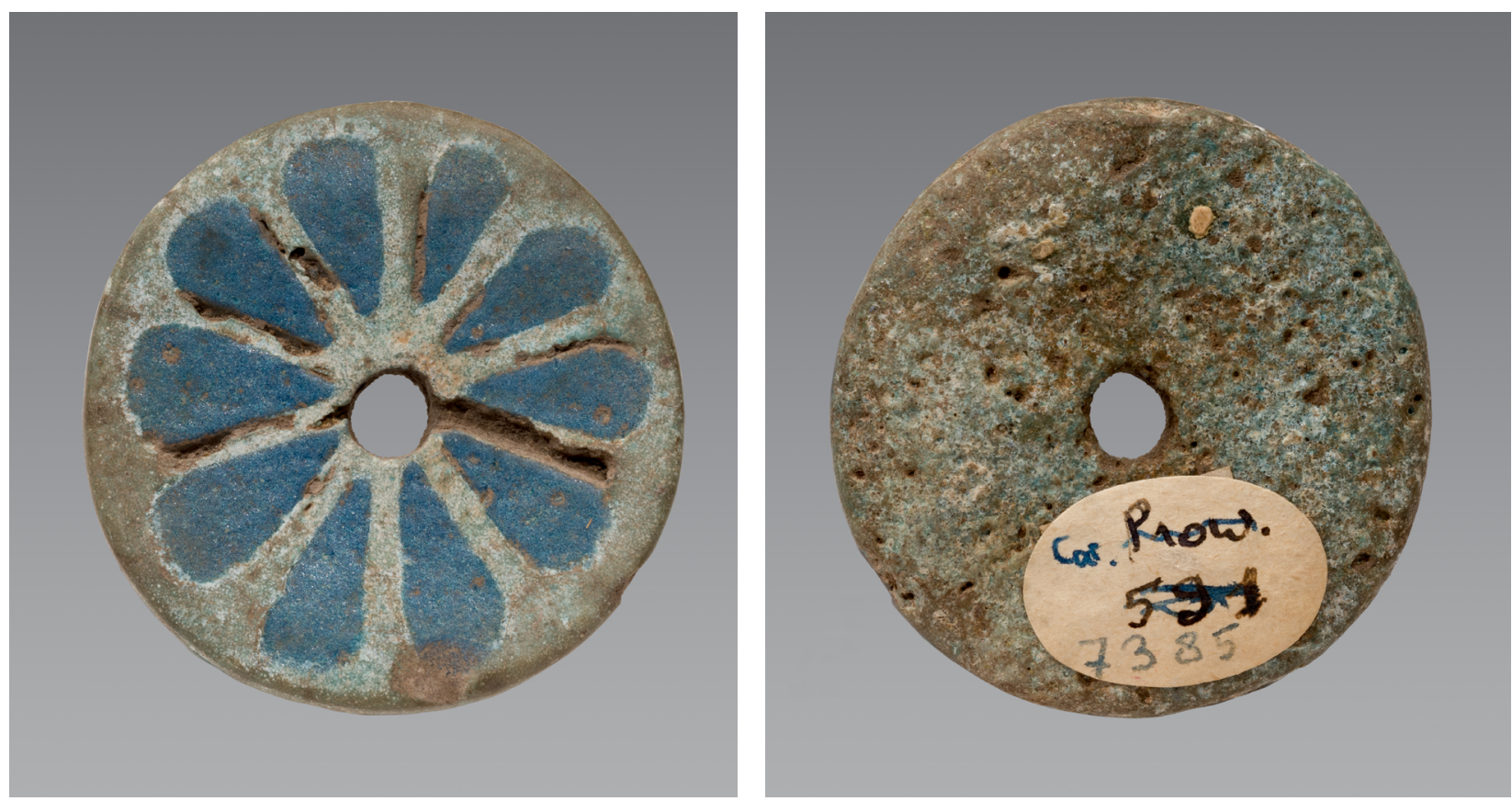

Fig. 3. Rosette disc Turin, Museo Egizio, Cat. 7385. Photo by Virginia Webb.

Provenance: Unknown.

Acquisition: It entered the collection of the Museo Egizio between 1824 (when the purchase of Bernadino Drovetti's collection established the Museum) and 1888 - when Volume Two of the Fabretti catalogue ${ }^{17}$ was published. Like Tile No. 1 , it may have formed part of Drovetti's sale to the Museum, but searches into the existing lists have not confirmed this (see discussion of Tile No. 1 above, under Acquisition). These three rosette tiles are relics of the mass-produced subsidiary decoration which was used in conjunction with the tiles representing the Nine Bows and other themes to decorate walls, floors, columns and the steps and upper surfaces of the throne daises mentioned above in buildings which relied on a range of faience tiles for their complete decoration. ${ }^{18}$ Earlier in the New Kingdom, carved hieroglyphs and scenes of the pharaoh and his god would have been enlivened with paint. But more and more it became the custom to insert elaborate faience tiles into the jambs of doorways - such as the fine cartouche of Ramesses III, now in the Oriental Institute Museum, University of Chicago, OIM 16721 from Medinet Habu - and then to decorate important elements of the building with faience tiles.

At Qantir, and later at both Medinet Habu and Tell el-Yahudiyeh, it became the aim for these smaller buildings, dedicated to certain ceremonies in honour of the Pharaoh, to be completely decorated with such tiles. ${ }^{19}$ For both Hamza and Hayes it was clear from the factory debris found at Qantir that the site was of especial importance to Ramesses II, who celebrated two of his jubilees there - according to inscriptions found there on two moulds for cartouches. ${ }^{20}$ Subsequent work has established beyond doubt that Qantir was the site of Piramesses - the great Delta capital of Ramesses II - a major city with vast military installations, which, significantly, had faience and glass factories, as well as bronze workshops for shields and horse harness, and vast stables for chariot horses. ${ }^{21}$ Here a building celebrating the power of the Pharaoh would have had an important place in the sequence of ritual structures.

\section{Tell el-Yahudiyeh-Leontopolis: the history of its discovery and destruction}

When such pieces turn up in collections, with little or no information about their provenance or the date of acquisition, it is often difficult to establish their exact source. More often than not, this is given as Tell el-Yahudiyeh - the site of an important temple of Ramesses III and associated palace (both now destroyed) in the Eastern Delta, which has indeed yielded many of these rosette tiles. ${ }^{22}$ An early example of the dismemberment of the building may be the rosette disc with pierced central hole, found in an Early Geometric 
burial in Rhodes (early 9th century BC). ${ }^{23}$ The history of the site, and the fate of the building, which was decorated with "enamel tiles", is succinctly given by Naville in his introduction to his excavations there. ${ }^{24}$ The monticule of Tell el-Yahudiyeh ("The Mound of the Jew") was an early focus for European savants and was given much attention because of its name and supposed association with the Bible story of the Exile of the Jews in Egypt. Carsten Niebuhr mentions seeing it, but from a distance of two leagues, and opined that it was the site of the city of Onias, and not (as previously believed) Heliopolis. ${ }^{25}$ According to Maspero, ${ }^{26}$

it had been pillaged since the beginning of the nineteenth century, and ever since the time of Champollion the Louvre has possessed figures of prisoners.

Linant had visited the site (possibly in 1825) ${ }^{27}$ and seen the process of destruction in full swing. ${ }^{28}$ And there is ample evidence from records of faience ro- settes and other tiles now in the Louvre that material was already being extracted from the ruins of the site in the first half of the nineteenth century. ${ }^{29}$ In 1854 M. de Longperier wrote about them in a catalogue (though he considered them to be Babylonian and was ignorant of their provenance), and as a result they were registered in the Department of Oriental Antiquities (many still bear AO numbers).${ }^{30}$ At a slightly later date - specifically in 1864 and 1868, more arrived in the Louvre, ${ }^{31}$ and their true origin was recorded.

The first to visit there for the purpose of study was Brugsch-Bey in 1870. His attention had been drawn to the mound because of some very fine enamelled tiles and inlaid ornaments which he had bought from a dealer. What he found was impressive, although it was apparently impossible to reconstruct the plan of the building. He brought back all of

3600 disks of various sizes, [...] (as well as) [...] tiles, flowers, birds, animal and portraits of Asiatic or negro prisoners, [...] fragments of hieroglyphic inscriptions,

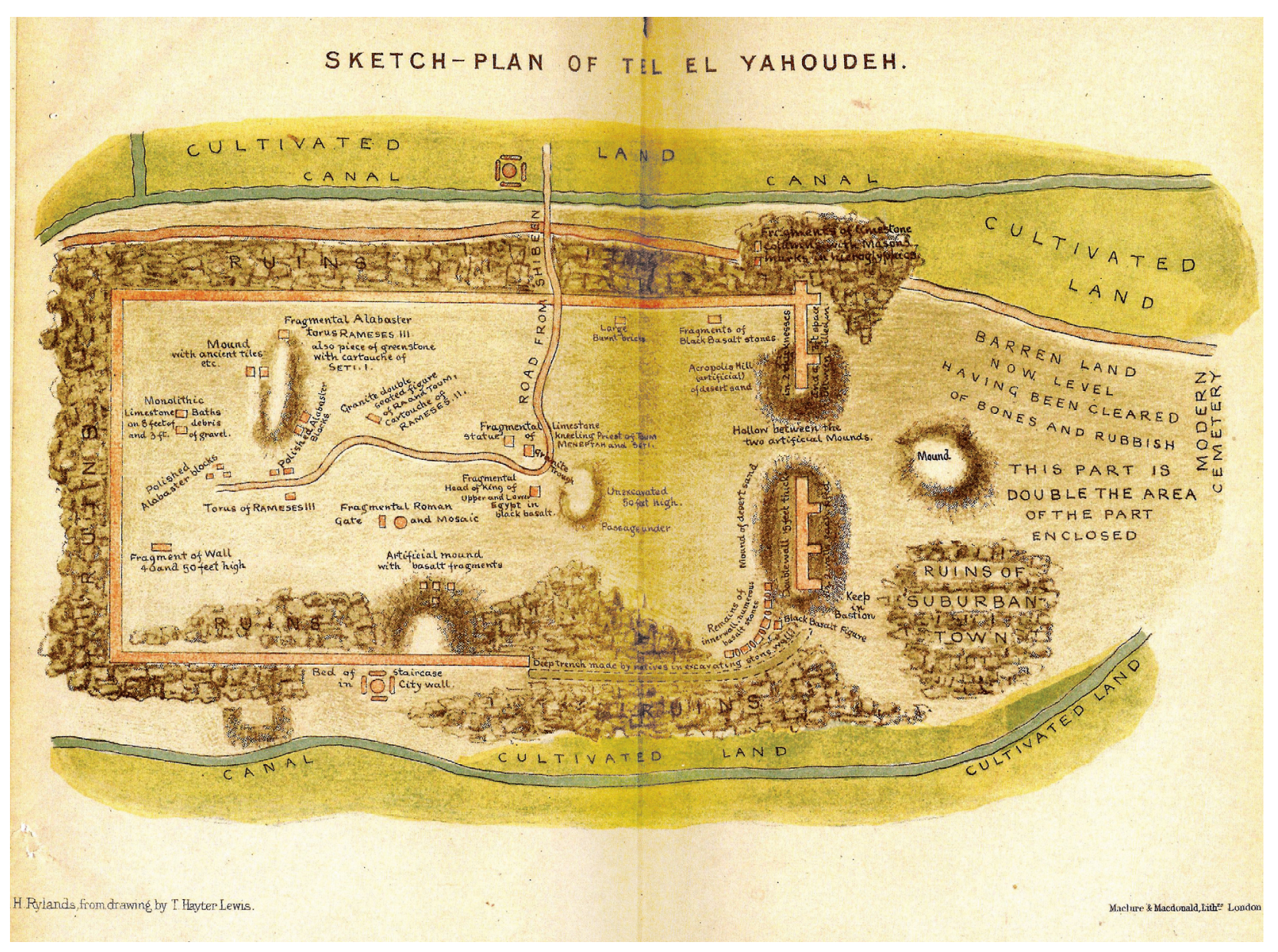

Fig. 4. 'Sketch plan of Mound of Tel el Yahoudeh.' From Hayter Lewis, TSBA 7 (1882), pl. between pp. 24 and 25. 
and these were all deposited

in the museum of Boolak (sic).

However, Brugsch-Bey regrets that he was not immediately able to institute excavations there in the summer of 1870, and adds that by the time he did start in the autumn,

ce retard avait suffit pour faire disparaitre une quantité considérable de ces monuments curieux, aujourd'hui dispersés dans les différentes collections de l'Europe. ${ }^{32}$

Amongst others, the English had already been there! Mr Eaton and Reverend Greville Chester had already explored/picked over the Tell, and their finds now in the British Museum (some originally in the Victoria and Albert Museum and elsewhere in London) were discussed in a paper by Professor Hayter Lewis. ${ }^{33} \mathrm{His}$ published plan is of some interest (Fig. 4).

In 1887, Gaston Maspero could write about the building which had yielded such material in a report. ${ }^{34}$ This account is echoed by Naville and Griffith, who were excavating in the same year, and what is more they opined that

the discovery [of the enamel tiles] has been fatal to the mound. There is no place in Egypt where the fellaheen have worked such wanton destruction, or so thoroughly carried away whatever could be taken. ${ }^{35}$

Subsequent excavation by Petrie in 1905-6 concludes the sorry saga:

A careful gleaning of the site of his [Ramesses III's] palace at Tell el Yahudiyeh has produced some dozens of pieces of the glazed tiles with figures, and shown that nothing more is to be hoped for from that ground. ${ }^{36}$

So what are we to make of a single rosette in the $\mathrm{Mu}-$ seo Egizio in Turin (Cat. 6824, No. 1 above) which actually has the name of the site written on its back, and the word "Egypt" in English? It must have ente- red the collection before the publication of the second volume of Turin Museum Catalogue in 1888, and presumably before the first English excavations took place in 1887 under Naville's direction (to be published in 1890). ${ }^{37}$ It seems most likely that it belongs with material collected by the English investigators in the middle of the nineteenth century. A give-away is the spelling on the disc, "Tel el Yahoudeh", which is exactly the spelling used throughout the article published by Hayter Lewis in 1882, based on the work carried out in 1870 by Greville Chester et al. ${ }^{38}$ Therefore it is most likely that our Turin example with its inscription in English is part of the material brought back by Eaton and Greville Chester. Only if we can identify the handwriting on the disc will we be absolutely certain of the route it took to the Turin Museum. An example in the British Museum Collection has "Tel el Yahoudeyeh" written on the face in black ink; the spelling is not the same, ${ }^{39}$ but the date of its acquisition - 1871 - is when the rosettes and other material collected by Eaton and Greville Chester, including hieroglyphs, rekhyt birds and a fully modelled tile of a Libyan prisoner were registered in the British Museum Department of Egyptian Antiquities (as it was then known) and elsewhere in England. This gives us our best clue as to when the Turin example reached the Museum. Brugsch-Bey had already commented on the pillaging of the site taking place in 1870 (see above) and the material from his excavations in autumn 1870 onwards $^{40}$ the only other possible source - was assigned to the Egyptian Museum in Cairo in toto.

The Tell el-Yahudiyeh rosette in Turin (Museo Egizio Cat. 6824 - No. 1 above) above is then most likely to have come from its stated provenance and to have been given to the Museum, or bought by it, at the time when English investigators were involved with the exploration and excavation of the mound. This means that Eaton and Chester Greville must have been the source (before 1871, in fact probably in 1870, as noted by Hayter Lewis and Brugsch-Bey above). It is of the size most commonly found in collections of Egyptian antiquities from Tell el Yahudiyeh - diameter ca $3.5 \mathrm{~cm}$ - and it is made in an identical fashion, with the same colouring glazes and technique $^{41}$ (see histogram of sizes of rosette discs in 
the Louvre, Fig. 14). Since rosettes similar in size to ours are the most commonly found in collections, we can also suggest that they were the most frequently made and used. However, there is a hierarchy of sizes, as we can see from those published by Petrie ${ }^{42}$ and Hayes, ${ }^{43}$ which clearly implies that the discs were employed in a variety of places in the building, and for a variety of decorative purposes.

\section{Heliopolis}

Rosette Turin S. 2763 (No. 2, Fig. 2) appears identical to No. 1, but has the stated provenance of Heliopolis, the important city dedicated to the worship of the Sun, which lies twenty kilometres to the south of Tell el-Yahudiyeh, and east of the Pelusiac branch of the Nile just north of where it splits off from the main stream of the Nile (now an outlying suburb of Cairo). Schiaparelli excavated at Heliopolis in 1903$6^{44}$ and although his records give the "scavi nel tempio" as a find-place, it has been suggested to me that this could have been a "plant" for bakshish, and that it actually came from Tell el-Yahudiyeh where, coincidentally, Petrie was excavating at the same time! ${ }^{45}$ However, there was also found at Heliopolis a more complex example of inlaid faience work, a lotus frieze, ${ }^{46}$ including miniature rosettes inlaid as daisies on either side of subsidiary papyrus plants (Fig. 5). Such fragments of lotus friezes are often found associated with the rosette discs from Tel el-Yahudiyeh. ${ }^{47}$ In publishing this piece, Enrichetta Leospo argues that the discovery at Heliopolis of

$$
\begin{aligned}
& \text { materie prime per la fabbricazione di oggetti } \\
& \text { in fritta, faience e vetro, associate con } \\
& \text { gli oggetti stessi, soprattutto amuleti, } \\
& \text { elementi decorativi, vasetti, piccole sculture, } \\
& \text { statuine funerarie, indica la presenza } \\
& \text { di un laboratorio templare specializzato } \\
& \text { in quel particolare tipo di produzione. }{ }^{48}
\end{aligned}
$$

However, this material was discovered in the area of the kom, to the north, and not in the Sanctuary of the Sun. ${ }^{49}$ Federica Ugliano ${ }^{50}$ is able to tell me from her study of Schiaparelli's notebooks that the rosette and the lotus frieze were found in the area of the Temple precinct, 50 metres east of the Great Obelisk, either during Schiaparelli's campaign there in 1903 or in that of 1904 (Fig. 6).

In addition, the present excavator of Heliopolis, Dietrich Raue is certain that this find does come from Heliopolis. I am very grateful to him for his comprehensive comments. He informs me

that somewhere in Heliopolis was some kind of royal resthouse/ceremonial room

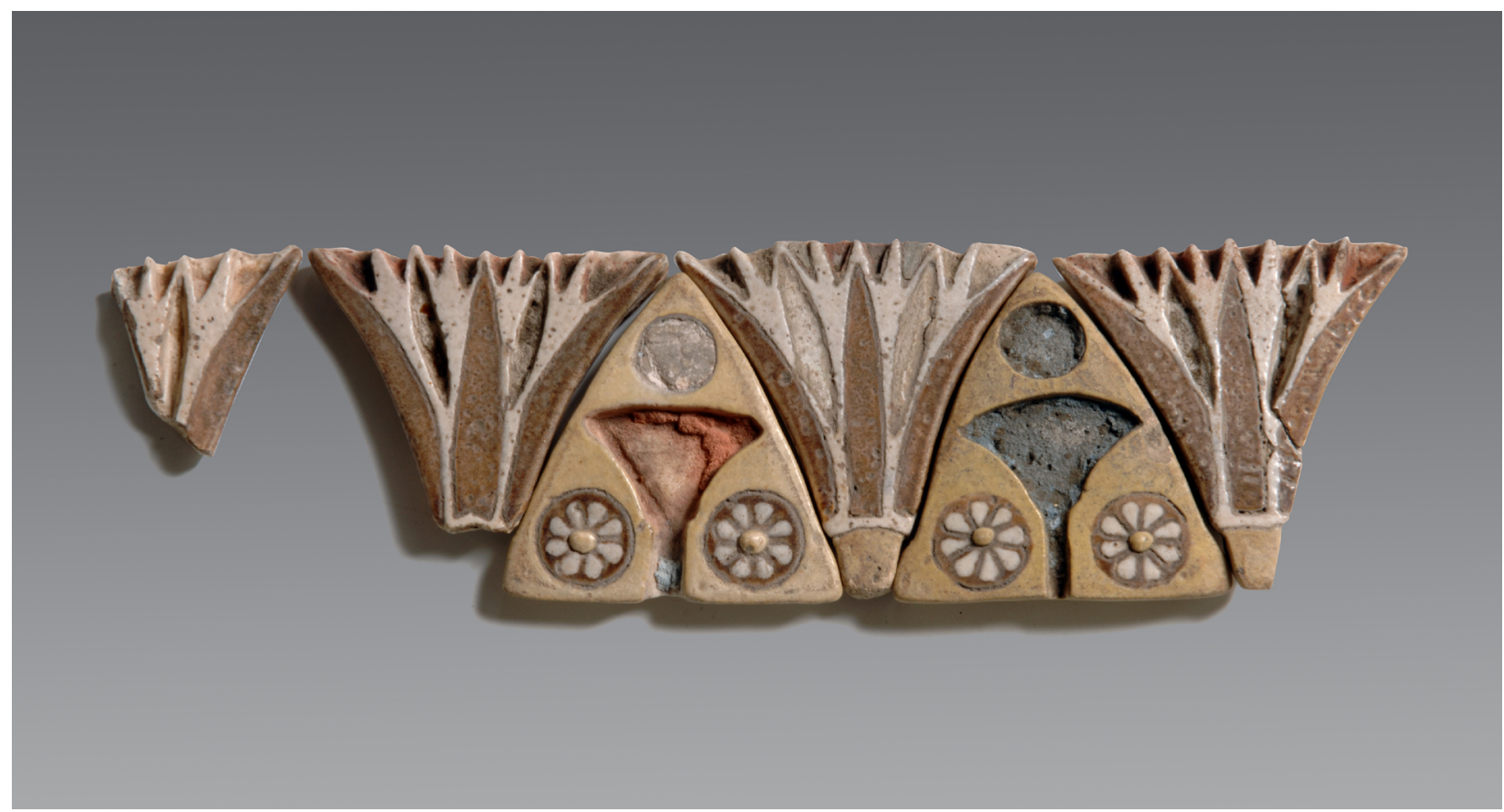

Fig. 5. Lotus frieze from Heliopolis. H. 4.5 cm. Turin, Museo Egizio, S. 2762. Photo by Museo Egizio. 


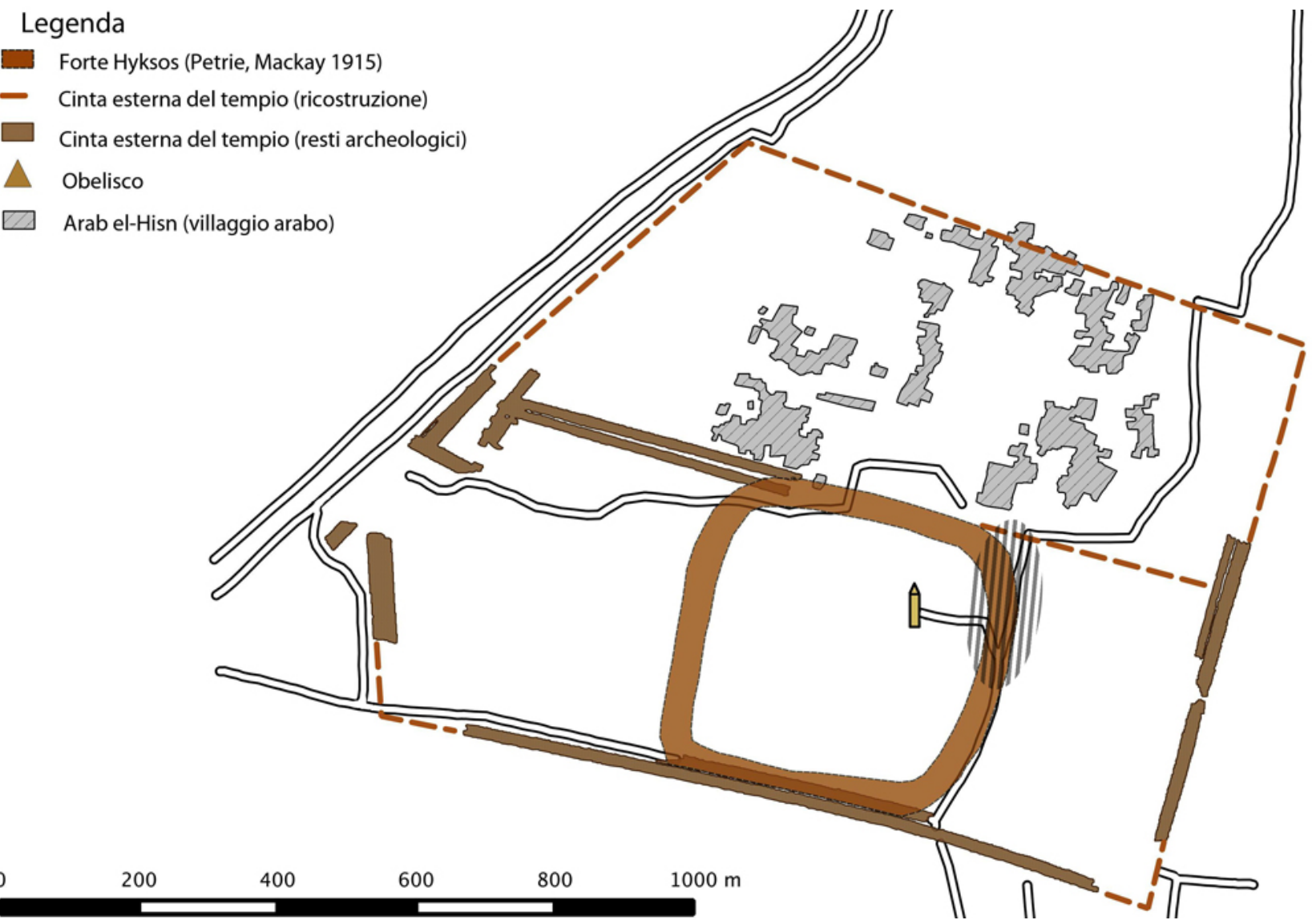

Fig. 6. Heliopolis central area showing outline of the temple of the sun god with the obelisk. From Saleh, Excavations at Heliopolos, I, p. 5, modified by Federica Ugliano.

for king's stays, made of mud-brick

with such a decoration, since we also have a cartouche-tile from Sethos II. ${ }^{51}$

Where precisely this structure might have been is not known. Raue continues:

There are many places where such a palace-like room unit could have been. The northern enclosure would fit of course, but there might have been ceremonial palaces in front of the at least four Houses of Millions of Years in the Main Temenos. Since Schiaparelli worked in both areas, the whole area of the great enclosure is possible as [the] location of provenance. ${ }^{52}$

(I would just add here that the room at Tell el-Yahudiyeh was built of limestone with alabaster flooring blocks, and not mud brick.)

There is therefore a strong probability that rosette S. 2763 (Museo Egizio S. 2763 - No. 2 above) not only comes from Heliopolis, as claimed in Schiaparelli's find list, but also that it was made there. However, more evidence of either similar material, or of workshop debris would be needed to confirm this. At the moment, the fact that it is identical to the Tell el-Yahudiyeh example still poses a problem - if not a "plant" from Tell el-Yahudiyeh, then the workshop making it at Heliopolis must have been contemporary and run on identical lines to that at Tell el-Yahudiyeh, with close contacts between the two sites. Even more likely is that both these seemingly identical discs tiles come from a common workshop, set up to supply both building projects. (See the discussion above, and the two small moulds for rosettes.)

\section{The third rosette}

The third rosette in the Museo Egizio, Cat. 7385 (No. 3, Fig. 3), is distinct from our other two, and presents a very different appearance. It is slightly wider than the other two examples, but much thicker in proportion (diam. $4.3 \mathrm{~cm}, 0.8 \mathrm{~cm}$ thick) and the form of decoration, colouring and number of petals also 
differs markedly. It is also true that the rosette has a distorted outline, and is less carefully delineated with secondary glaze colour. It has ten petals of varying size, coloured dark blue against a light blue background. As in the other rosettes, they radiate from a notional centre. The petal material is probably inserted into previously moulded or cut-out cells made in the main body of the rosette -but here the technique has been used with much less care than in the other two examples (Nos. 1 and 2), and there is no tertiary application of an overlying and inserted inlay (buff-brown) between the petals like that used in the other two examples discussed above. (See the section on Manufacturing Technique below.) Centrally pierced with a distinct hole, the back is slightly convex, with a coarse bubbled surface bearing traces of blue - the remains of a blue glaze.

This piece therefore, although presumably intended for similar decoration in a building, most probably comes from a different source. There are no parallels for either the number of petals, colouring, or techni- cal details amongst the Tell el-Yahudiyeh finds. This is the point where we should look at the well-documented material from Qantir, a large part of which is now kept in the Metropolitan Museum New York. The other large collection is in the Cairo Museum. More recent excavations have discovered more waste material from the factory debris. ${ }^{53}$ Here we find rosette discs with ten petals, and with a very strong use of blue, which appear to be much more similar to our piece No. 3. A selection are published by Hayes. ${ }^{54}$ (See below for a Table of comparative sizes and Fig. 7 for a selection of types and their colour range.)

\section{Qantir - the site of a Temple and Palace of Ramesses II}

Excavations at the village of Qantir/Kantir were initiated in 1928 by the Director of Antiquities as a result of faience material coming onto the antiquities market. ${ }^{55}$ Qantir, a village in the Eastern Delta not more than twenty five kilometres south of Tanis, had previously been neglected by archaeologists, although Petrie on a brief visit "had identified it as

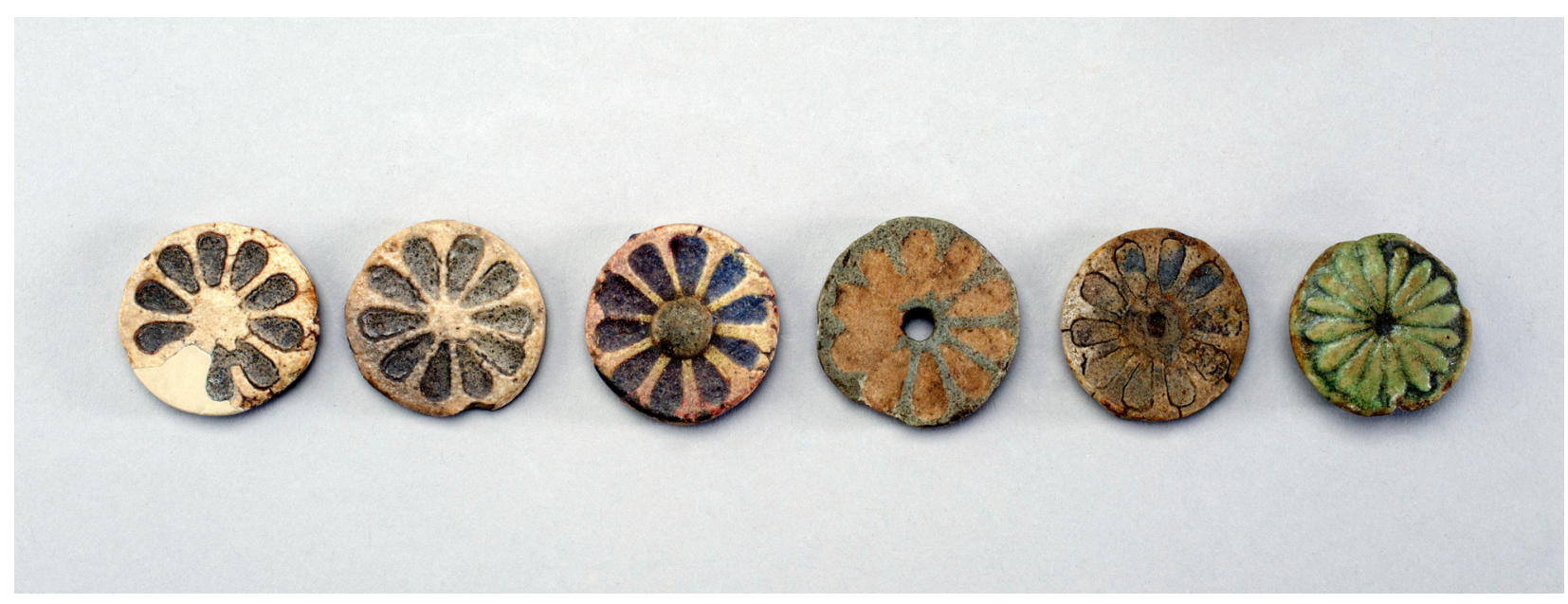

Fig. 7. Rosette disc tiles from Qantir/Piramesses. New York, Metropolitan Museum, 35.1.134-139.

Courtesy of the Metropolitan Museum.

one of those Delta cities which was embellished by Ramses II". ${ }^{56}$ It is now argued indisputably that it is the site of Piramesses - the Delta capital of Ramesses II. ${ }^{57}$ Mahmud Hamza's excavations confirmed that the source of the faience material was Qantir, although he was unable to excavate the Palace itself, which he thought probably lay under the modern cemetery. ${ }^{58}$ What he did find however, at a distance of sixty metres or so, was substantial evidence of "a faience and glazing factory of great size". ${ }^{59}$ (Qantir is now the site of long term investigations which have revealed very large glass and metal manufacturing workshops. $)^{60}$ For the relationship between the finds made by Hamza and the more recent excavations, see Figs. 8, 9. ${ }^{61}$ In the debris from the glazing workshop were found many tiles bearing the name 
and titles of Ramesses II (more than for any other royal personage), rosette tiles and other decorative forms, about ten thousand terra-cotta moulds, and other evidence of the manufacturing process. Many of the moulds were for rosette tiles. Alongside hand-modelled statuettes, there were also tiles depicting the subject peoples, small figures of divinities and amulets, and beads. ${ }^{62}$ This material found its way both to the Cairo Museum and the Metropolitan Museum New York and, as a result, further work was undertaken by W. C. Hayes which concen-

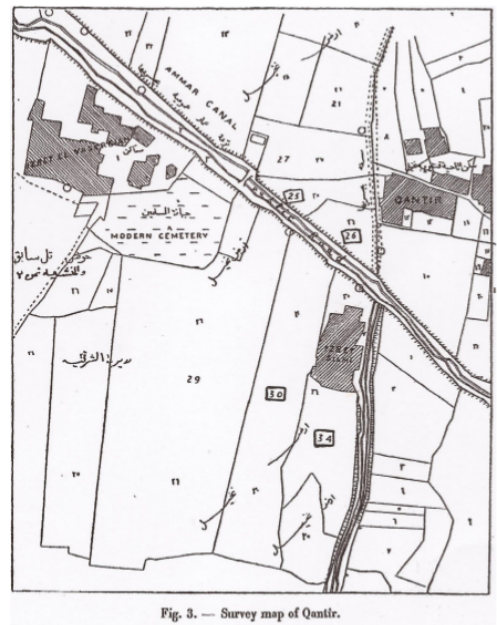

Fig. 8. Plan of Qantir, showing areas excavated by Mahmud Hamza in 1928. From Hamza, ASAE 30 [1930], fig. 3, p. 40.

constructed the complete throne daises, with their shallow steps and supporting walls decorated with the subject races, and a large animal (lion) seated at the base of the steps, consuming an apparently Asiatic enemy. ${ }^{65}$ In the Metropolitan Museum there are large fragments of such constructions. ${ }^{66}$ However, it would seem that the throne daises at Qantir were rectangular in form, with shallow steps leading up to them, and that this design, modelled on that found elsewhere in New Kingdom Egypt, does not correspond to the semi-circular stepped structures identified at Tell el-Yahudiyeh, although it is possible that they shared the same purpose. As far as the rosette tiles at Qantir are concerned, Hayes is unable to say where they were used, although he is certain they were

incrusted, to form over-all patterns, in both trated on reconstructing the actual decoration of the Palace.

The description

of semi-circular stands rising in steps ${ }^{63}$

at Tell el-Yahudiyeh seems to be paralleled by the throne daises at Qantir which were reconstructed by Hayes. ${ }^{64}$ Hayes established the positioning of these tiles in the scheme of the palace decoration, identified the nationalities depicted, and in particular re-

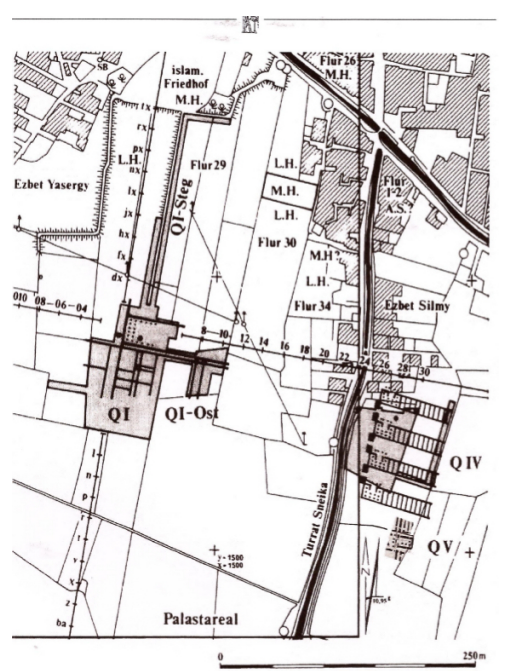

Fig. 9. Plan of Qantir, showing areas excavated by Hamza, Pusch and Rehren (QI, IV and V). From Pusch and Rehren, Hochtemperatur-Technologie in der Ramses-Stadt, map 01, p. 20.

wall and column surfaces. ${ }^{67}$

How then, did they make rosettes and to what design, and what link is there between these products made in the reign of Ramesses II and those used to decorate the building at Tell el-Yahudiyeh made in the reign of Ramesses III?

From Qantir we have two distinct types of rosette (Fig. 7, Fig. 10 and Table 1). (I restrict this list to rosette disc tiles with a central knob or pierced hole. Hayes illustrates a selection.) ${ }^{68}$

Although the three large discs have ten petals (not eight) they are identical in design to those found at Tell el-Yahudiyeh with flat, outlined petals, flush surface, and central perforation. However the colouring is different (as noted above) alternating bright blue and buff, in positive and negative forms, in the large examples (A), or with a dark blue on lighter 

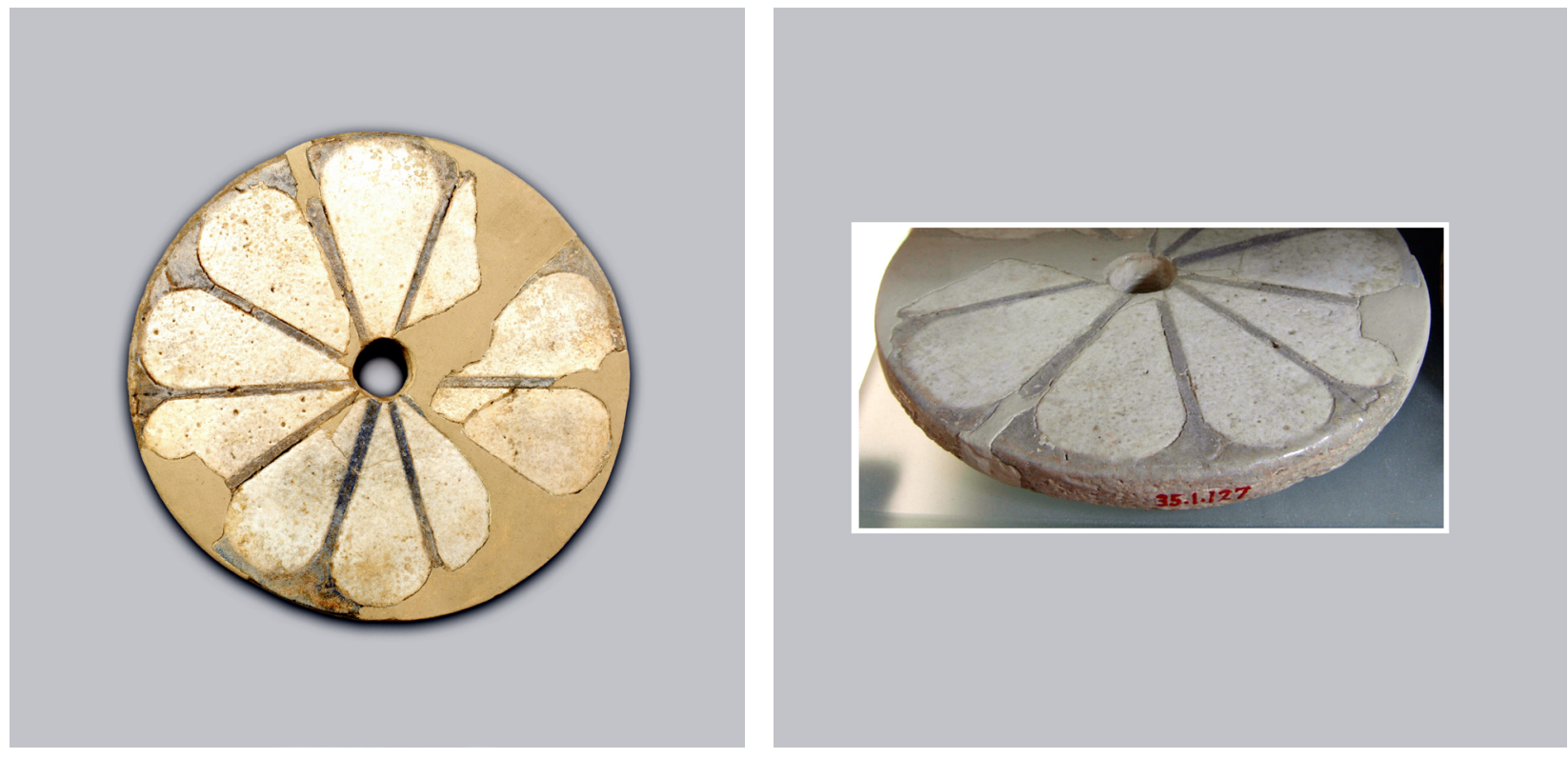

Fig. 10. Large rosette disc tile (twelve petals) from Qantir/Piramesses, Met Mus New York 35.1.127. Diam. $11.5 \mathrm{~cm}$. Courtesy of the Metropolitan Museum.

\section{Table 1}

Table of comparative sizes of Rosette disc tiles from Qantir/Piramesses in the Metropolitan Museum, New York (based on information supplied by the Metropolitan Museum).

Design A - (Fig. 10) Ten-petalled precursors of the eight-petalled flat-surfaced rosettes.

\begin{tabular}{|c|c|c|c|c|}
\hline & Mus. no. & Diam. cm & Th. cm & 1.3 \\
\hline Large: & 35.1 .127 & 11.5 & 1.4 & $\begin{array}{c}\text { Ten white/buff petals } \\
\text { on grey/blue }\end{array}$ \\
\hline & 35.1 .128 & 11.5 & 0.9 & $\begin{array}{c}\text { Ten bright blue petals } \\
\text { on buff }\end{array}$ \\
\hline Medium: & 35.1 .129 & 7.0 & on betals \\
\hline
\end{tabular}

Design B - (Fig. 7) Ten-petalled cruder, small rosettes with dark blue petals decorating the upper surface (similar in design and technique to our example No. 3 Turin Cat. 7385).

\begin{tabular}{|c|c|c|c|c|}
\hline Small: & 35.1 .131 & $3.8 \mathrm{~cm}$ & $0.5 \mathrm{~cm}$ & 10 blue petals on buff \\
\hline & 35.1.132 & $3.2 \mathrm{~cm}$ & $0.4 \mathrm{~cm}$ & “" \\
\hline & 35.1 .133 & $3.4 \mathrm{~cm}$ & $0.4 \mathrm{~cm}$ & ““ \\
\hline & 35.1.134 & $3.2 \mathrm{~cm}$ & $0.4 \mathrm{~cm}$ & ““ \\
\hline & 35.1 .135 & $3.3 \mathrm{~cm}$ & $0.4 \mathrm{~cm}$ & ““ \\
\hline & 35.1 .136 & $3.2 \mathrm{~cm}$ & $0.4 \mathrm{~cm}$ & “" \\
\hline & 35.1.137 & $3.4 \mathrm{~cm}$ & $0.4 \mathrm{~cm}$ & “ “ \\
\hline & 35.1 .138 & $3.0 \mathrm{~cm}$ & $0.4 \mathrm{~cm}$ & ““ \\
\hline
\end{tabular}

Design C (Fig. 7, extreme left) Sixteen-petalled rosette, with petals applied in relief onto surface. (Cf. Petrie, Tell el Amarna, pl. XVIII, no. 427.) 
blue background in the smaller examples (B).

So, would we be justified in identifying Qantir as the source for our piece No. 3? One argument against this is the different size ratio of the Turin piece bigger but also much thicker in depth. The other drawback is that the site at Qantir was apparently not discovered until the early twentieth century. This does not of course rule out the accidental discovery of such pieces - as indeed it was such discoveries which caused the exploratory excavations of Mahmud Hamza in 1928, and as he says:

the precious antiquities of this village were known for long to illicit diggers and dealers. ${ }^{69}$

The other possibility is that our rosette tile comes from yet another palace building of Ramesses II, so far unidentified - a not impossible scenario!

Of course, up to now we have been looking only at the three sites in the Eastern Delta where the Ramesside Pharaohs were very active, Qantir - Ramesses II, and Tell el-Yahudiyeh and Heliopolis (?) - Ramesses III. However, the great complex of buildings at Medinet Habu, in Western Thebes, had a Palace of Ramesses III attached to his Mortuary Temple, where faience tiles were used lavishly. ${ }^{70}$ What were the rosette tiles like here? In one of the excellent volumes of excavations on behalf of Chicago Oriental Institute by Uvo Hölscher, Rudolf Anthes ${ }^{71}$ illustrates the type of rosette tiles found at the site. These are either eight-petalled with white petals laid into grey, buff or brown background (Chicago 16023-51) (pl. 37.k on the left) - very similar to the most common type from Tell el-Yahudiyeh - or are more sophisticated ones with inlaid petals (again eight in number) in different colours and more varied materials - either faience or glass (Chicago 16622-30, pl. $37 \mathrm{k}$, on the right). There is no sign of the types found at Qantir, either the fine ten petal rosette-type, or the cruder smaller type (also with ten petals), in dark blue laid onto the surface in a careless fashion, which is closest to our Turin Cat. 7385. Therefore we can also rule out the Palace of Ramesses III at Medinet Habu as a possible source. In other words, our Turin piece seems most likely to have come from Qantir, or from another site where there is a similar building of the reign of Ramesses II.

\section{The building at Tell el-Yahudiyeh}

I would like to explore what the building was like. Two descriptions exist starting with that of Naville after Brugsch-Bey who describes the structure as

a Pavilion - a chamber lined with enamelled tiles. Fragments of columns and pillars, and traces of an alabaster pavement. $^{72}$

Griffith goes further in his description of the building

which lay at the west end of the temple [of Ramesses III, destroyed]: The floor was of oriental (sic) alabaster; the roof was supported by columns resting on bases of alabaster and red granite; the limestone walls were covered with patterns in mosaics, and their uniformity was broken by semi-circular stands rising in steps, each of which was ornamented with rosettes and other devices in variegated enamel. ${ }^{73}$

[A photograph reproduced by Petrie shows some of the alabaster floor blocks in situ] ${ }^{74}$

In the Cairo Museum

there exists an ornate pedestal with two semi-circular platforms

which has bands of rosettes on its sides. This is Hayter Lewis's description of the structure he illustrates (Fig. 11) ${ }^{75}$ and corresponds exactly with Crowell's description:
A line of the larger rosettes is set along the base with a second row of smaller ones above. On the top, surrounding a lotus flower design, large and small faience rosettes form an attractive all-over decorative pattern. ${ }^{76}$

In the Cairo Museum there is also a large fragment of limestone (hacked away from its original setting) which may be part of the same or similar object and which preserves at its base a flat horizontal step (?) projecting out horizontally, above which is a hori- 


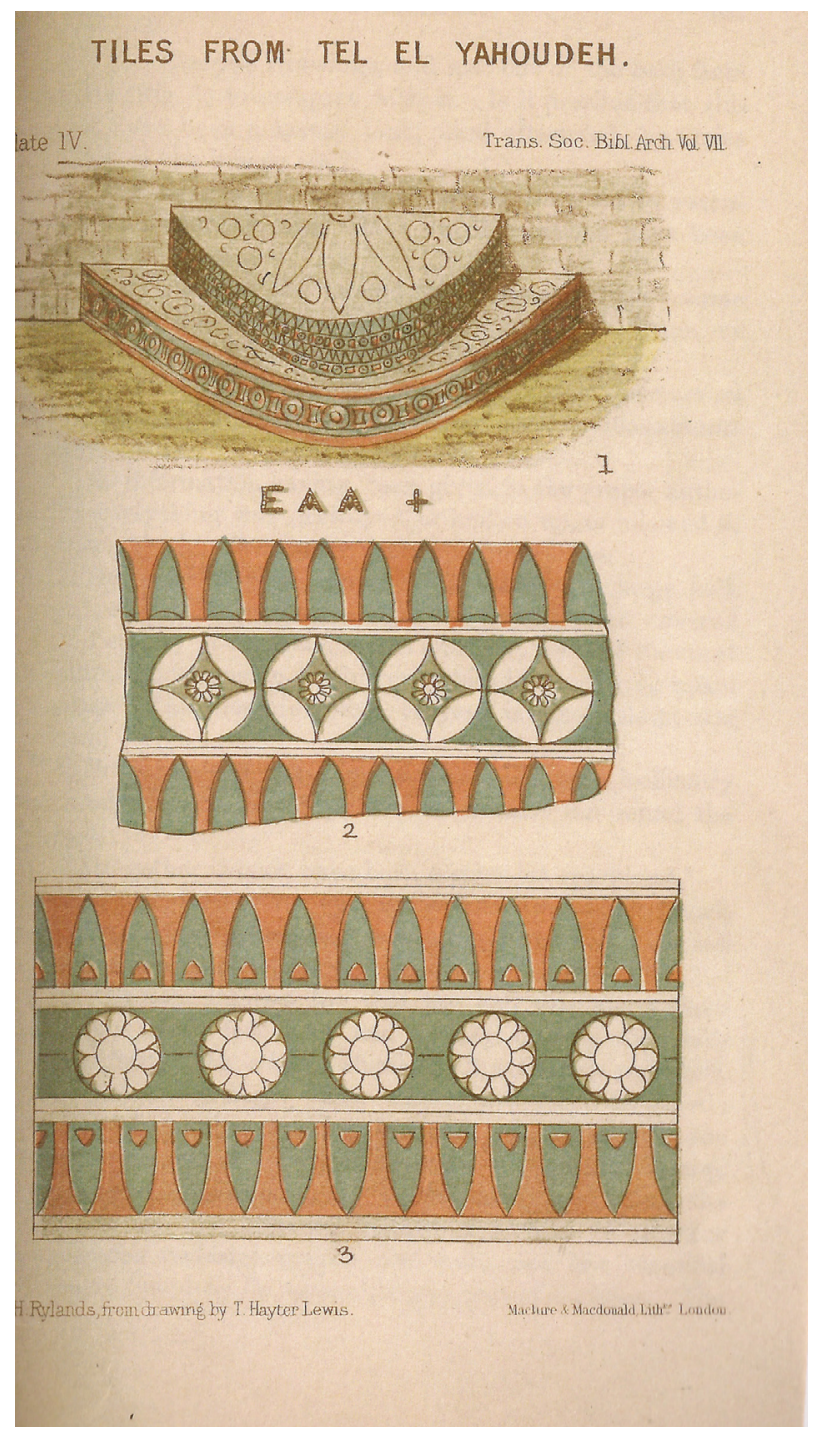

Fig. 11. Semi-circular stand rising in steps.

From Hayter TSBA, pl. IV.

zontally curved vertical surface (of an engaged column or step?) all the surfaces of which are decorated either with faience disc tiles or stone inserts ${ }^{77}$ (Fig. 12). This has a central row of eight-petalled rosettes, set into a cut-back channel, which is defined above and below by raised horizontal ridges cut out of the limestone, and with the remains of vertical lotus and petal friezes above and below it, which retain the traces of upright lotus petals originally affixed to the surface. $^{78}$

In the British Museum there survives an almost identical example also from Tell el-Yahudiyeh, ${ }^{79}$ this time with the central row of rosettes of the rhomboid diamond type, ${ }^{80}$ and with the lotus frieze above and below still intact (Fig. 13).

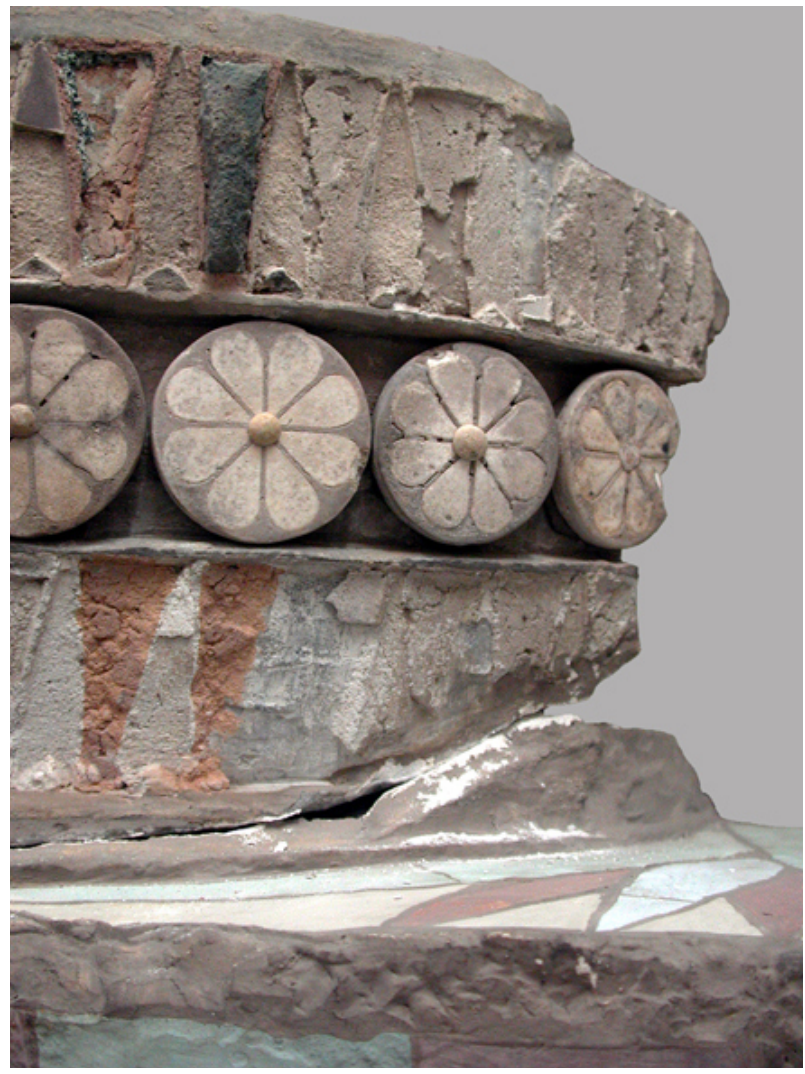

Fig. 12. Semi-circular column base or stepped platform decorated with rosette disc tiles, from Tell el Yahudiyeh. Cairo Museum, no number. Courtesy of Guy Lecuyot.

Pieces are of white limestone (hacked out of their original context), and not retaining any trace of backing wall. It is therefore not now possible to restore the original structure, except by relying on Hayter Lewis's drawing (Fig. 11). The three disc rosettes in Turin of course are on a smaller scale than those used in the central channel on these two semi-circular structures - the first two measure $3.5 \mathrm{~cm}$ in diameter, much smaller than the ones inserted in the semi-circular step, and in fact belong to the most common category in size, while the third, $4.3 \mathrm{~cm}$ in diameter, is slightly larger. (See the attached graph of size distribution based on the discs in the Louvre Collection, Fig. 14.)

Our first two Turin rosette discs must belong either to the decoration which Hayter Lewis describes on the top of the structure, or from elsewhere on walls or floors. Since they are not pierced for attachment, they must have been attached by gypsum plaster or other adhesive to a surface which did not take heavy 

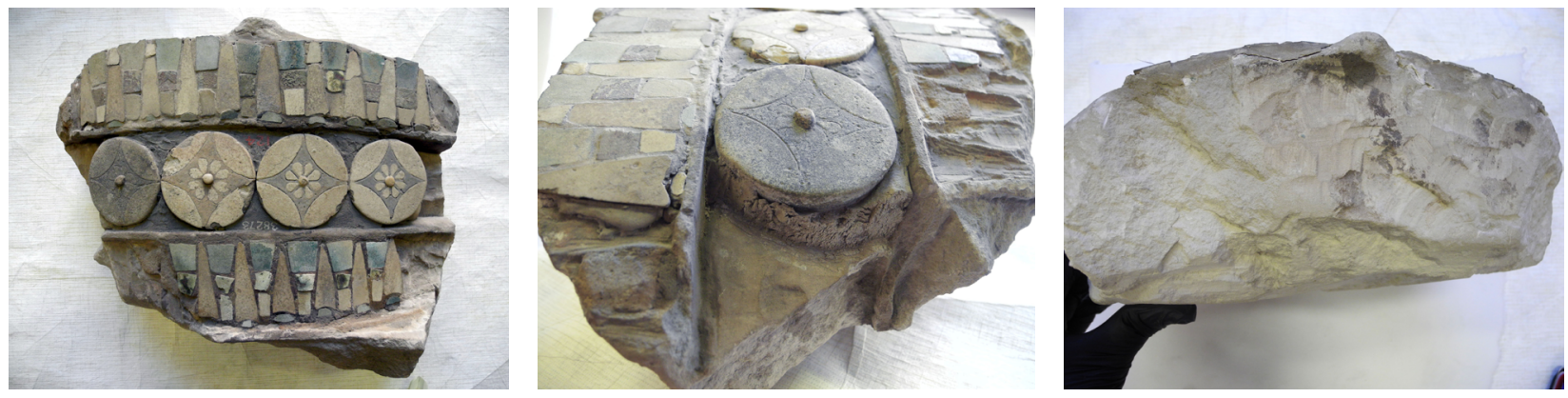

Fig. 13. Semi-circular column base or stepped platform decorated with rhomboid diamond disc tiles, from Tel el Yahudiyeh. Width $27 \mathrm{~cm}$, depth $19 \mathrm{~cm}$. BM EA 38273. Courtesy of the Trustees of the British Museum.

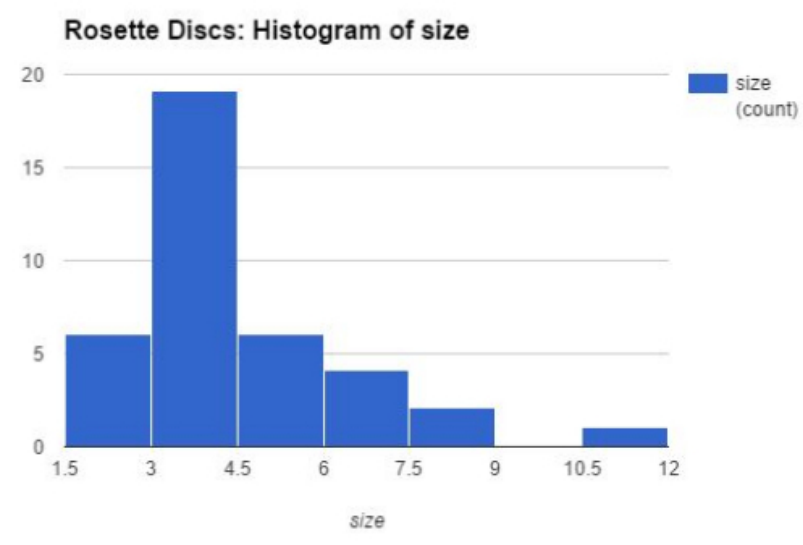

Fig. 14. Graph showing variations in size of rosette discs from Tell el Yahudiyeh in the Louvre Museum, Paris (from information provided by Geneviève Pierrat-Bonnefois).

wear. By contrast our third disc - Museo Egizio Cat. 7385 - No. 3 above - is pierced, but cannot be compared with those Tell el-Yahudiyeh discs, which have copper nails pierced through for attachment to a surface, and which are, at least in the British Museum Collection, very dirty and worn: these are also amongst the smallest of all known types (e.g. EA49518 - $2.25 \mathrm{~cm}$, EA49517 - $2.55 \mathrm{~cm}$, EA49516 $-2.7 \mathrm{~cm}$ ) and must presumably have been near or at floor level. Most importantly, it is still unclear whether these two semi-cylindrical limestone fragments are part of engaged columns, or of a steplike dais structure, such as Hayter Lewis illustrates. Lastly, we do not know where our tiles were actually placed, and we will probably never know, unless by some stroke of good fortune a similar building is found with its decoration intact! ${ }^{81}$

\section{Manufacturing Techniques}

How were our tiles made?

Of great interest to us are moulds of terracotta, par- ticularly the ones found at Qantir. Hamza collected more than ten thousand, which included about 800 varieties. $^{82}$ There were moulds for fruits and flowers, ${ }^{83}$ for grape vine bunches, and for rosettes. We can compare the grape bunches with actual finds from Medinet $\mathrm{Habu}^{84}$ and with the moulds and objects found at Tell el-Amarna, dating to the period of Akhenaten, and clearly showing a strong continuity of tradition..$^{85}$ Rosette forms were particularly popular at Qantir, occurring in a variety of sizes and including rosettes with ten petals, but also with twenty-four, sixteen, twelve and eight petals. ${ }^{86}$ The combination of mould-made blanks and the use of inlay must account for the fine quality of the best from Qantir (Hayes pl. XIII, D kk = 35.1.28, 35.1.27 . and this is the technique which is transferred exactly to the workshops of Tell el-Yahudiyeh (and used in the workshops producing for Medinet Habu).

Pamela Vandiver ${ }^{87}$ describes the methods used to produce the range of tiles so widely made in the New Kingdom, focussing especially on the techniques of inlay. She writes that the
common method is (by) incising a channel and inlaying with a body material of contrasting colour. Inlay usually is applied into an incised groove after the body has begun to dry. The inlay shrinks away from the body as it dries, thus a division between the inlay and the background occurs which forms an outline around the inlay.

Examination of a broken example of a twelve-petalled disc - most probably to be included in Petrie's Tell el-Yahudiyeh material (Petrie Collection UC 
29536) (Fig. 15) -shows clearly that after the petals themselves had been formed with a moulded template - which also stamped out the shape of the tile itself - the lines in between the petals were deeply grooved into the body material of the core with a sharp instrument; this must have been done after the cream petal material had been inserted into the moulded cells. Finally, the buff brown glaze material of the inter-petal divisions, rim and the upper part of the side was run into place in the grooves, and then wiped off smooth, leaving the surface completely flush. ${ }^{88}$ It is clear from many of the rosettes that the dark brown colour filling in the narrow margin between the petals has shrunk away from the edge, leaving distinct lines on either side, a very clear indication of the inlay method described by Vandiver. The other account of their manufacture is given by Nicholson:

Other [New Kingdom] tiles are polychrome by virtue of deliberate and obvious inlay; these include the well-known 'daisy tiles', in which white and yellow flowers are set into circular voids in the green background, good examples of which are to be found in the Metropolitan and Petrie museums. $^{89}$

This description tallies well with the simpler technique of our Tile No. 3, where there is no evidence of inlay shrinkage round the edges of the petals and where the shape of the mould would have impressed a hollow into the upper surface for each petal. However, this explanation does not account for the fact that in Nos. 1 and 2 the layer of dark brown glaze material, which fills the grooves between the petals, also flows over the edge of the flush upper surface to end in an indeterminate line halfway down the outer edge, overlapping the cream glaze of the petals. This was clearly formed later than the cream glaze. It must therefore have been added as the final stage of colour application, and not, as Nicholson implies, as part of a background - i.e. earlier - layer. As Nicholson states elsewhere in his article on "Egyptian Faience", many of the moulds from Tell el-Amarna still contain residues of the efflorescence technique, as do disc rosette moulds found by Hamza at Qantir. For Tell el-Yahudiyeh, we have no workshop debris, as it was the actual building which served as a source for the material. From Qantir we have moulds, but I have not had the opportunity to examine them; their analysis must be left to further research. Finally, as Vandiver puts it:

For the boss [on the rosette tiles] the [yellow-lead antimoniate] faience is placed on the surface in relief.

Thus, the 'applied' technique was used. Of interest also is that the core, visible in broken examples of rosettes in the Petrie collection both with twelve petals (UC 29536, Fig. 15) and rhomboid diamonds (UC 29646 = Petrie, Hyksos and Israelite Cities, 17, pl. XVIA, no. 14 and 29748- unprovenanced) is a coarse,
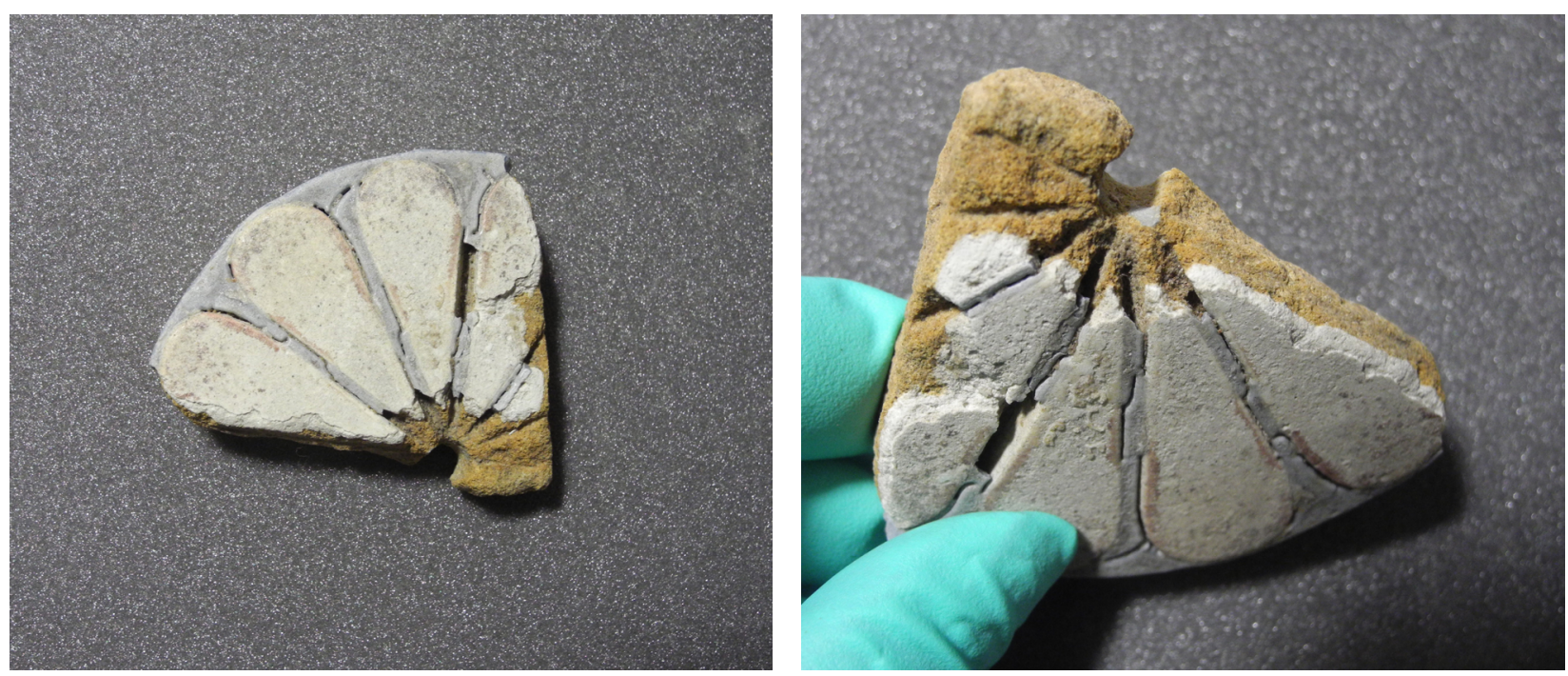

Fig. 15. Rosette disc tile, detail of core and incision technique. Diam. (surviving) 5.2, th. 1.1-1.2 cm. From Tell el Yahudiyeh. UC 29536. Courtesy of the Petrie Collection. 
orange brown sandy material. No analysis has been done so far, (though compare that of the Qantir material published by Hayes ${ }^{90}$ but it would seem obvious, that at least in these examples, the glaze cannot be effloresced from the core, which is not of the same colour or fine texture. Whether a thin layer of faience material could be laid on the core which would itself both adhere and effloresce, I am not in a position to say. As Nicholson says ${ }^{91}$

It can be very difficult for the archaeologist to determine glazing methods - even where it is possible to examine a cross-section - for instance, most reliably with the scanning electron microscope SEM.

There may well have been a mixture of techniques - using both "efflorescence" and "application" methods. Whatever sequence of techniques were in place for the manufacture of the rosette discs, it was already established at Qantir, and quite possibly at Tell el-Amarna, and it produced hard-wearing and long-lasting objects. Moreover, it was both an effective and reproducible technique, which resulted in thousands of discs, in different sizes, from under 2 $\mathrm{cm}$ to nearly $12 \mathrm{~cm}$, which survive to the present day. The opportunity to examine the moulds and to use SEM technique to establish the exact nature of the bonding layer between the core and the glaze would be a valuable step in establishing the exact technical skills which were used.

\section{Colouring}

A final note must be made about the colouring of the discs. The now rather indeterminate dark brown, almost khaki background colour which survives for the inlay between the petals on tiles Nos. 1 and 2 was very likely originally a blue-green colour. (This colour change can be seen in the small cups of faience which make up part of the Foundation deposit of Ptolemy II at the temple precinct rebuilt for Amon Re at Naukratis.) $)^{92}$ Now an indeterminate khaki colour, they must originally been a blue-green derived from a copper oxide. Certain photographs of Tell el-Yahudiyeh discs show a blue tinge, and the more varied and earlier disc material from Qantir (Piramesses) varied in terms of size, number of petals, and colour combinations - shows a range of blue tones from a dark cobalt (?) blue to a pale sky-blue. The existence of dark blue on its petals would suggest another reason for ascribing our No. 3 to a related workshop tradition. Another reason for this range of blue tones might be the close proximity of the bronze working foundries, from where a range of copper and cobalt based elements would be easily obtainable. The glass ingots produced at Qantir-Piramesses, by contrast, relied on cuprite oxide to produce a red colouring. ${ }^{93}$

\section{Conclusion}

What our little rosettes show is that these workshops were centres of excellence and innovation, and that the faience workshops not only built on the best of the working practices that had gone before, but established new standards, and these in their turn were copied and carried to other workshops. The high standards and rule-based practices of Egyptian technical production guaranteed this. Moreover, we are given clear examples of the enormous energy and refinement invested in the manufacture of faience tiles for these Palaces, or Rest Houses, created in what was considered an eternal and magical material, ${ }^{94}$ and one which would give a gleaming and colourful backdrop to the Divine presence of the Pharaoh. The rosettes played their part in providing a gloriously complete decoration. It would not have occurred to the Pharaoh or his Chief Architect that precisely these features of the decoration would be the cause of the destruction of the buildings in their afterlife. 


\section{Notes}

${ }^{1}$ Linant de Bellefonds, Mémoires sur les principaux travaux, p. 117.

${ }^{2}$ Petrie, Tell el Amarna, describes in detail the quality and extent of the faience decoration in Palace rooms. Columned Hall and Harem, pp. 11, 12, 27, 28. Daisies on glazed tiles along west side of the great hall of columns p. 28a, almost all of which had been removed for re-use elsewhere, and the daisies picked out p. 12b; moulds show the variety of forms pl. XVIII, nos. 353-356, 399-440, pl. XIX, nos. 498-500. See also Freed at al. (eds.) Pharaohs of the Sun, pp. 137, 261; Williams, Swansea Newsletter, Inscriptions 23, (2007), p. 4, W1265 EES.

${ }^{3}$ Recent excavations at Elephantine have yielded a number of glazed tiles, but it appears that they belong to foundation deposits, and are not the decoration of buildings. I am grateful to Johanna Sigl for this information. Personal communication $10-11 / 1 / 2017$.

${ }^{4}$ Hayes, Glazed Tiles from a Palace of Ramesses II, pp. 8-10 and passim.

${ }^{5}$ Hayes, Glazed Tiles from a Palace of Ramesses II, p. 8.

${ }^{6}$ Schlick-Nolte and von Droste zu Hülshoff, CAA, no. 52, pp. 102-03, and diamond rhomboid, no. 49, pp. 100-01; Crowell, in Friedman (ed.), Gifts of the Nile, nos. 33, 34, 35, p. 197; colour figs. pp. 77, 87; Hepper, Pharaoh's Flowers, pp. 13-14 and passim; Manniche, Sacred Luxuries, pp. 115-16; Williams, Swansea Newsletter, Inscriptions 23 (2007), p. 4, no. EC515 - two examples - a large piece (half survives); a smaller piece (a fragment only).

${ }^{7}$ Petrie, Tell el Amarna, pl. XVIII; nos. 415, 419 with twelve petals provide the prototype for our later rosette discs. Compare with the simple rosettes employed in the Near East, e.g. Nimrud British Museum ME 130868-70, 130874-76 as ceremonial dress or harness attachments, which have 12 simple petals and a central projecting knob. When the Tell el-Yahudiyeh discs were first recorded in the Louvre, in 1854, they were mistaken for Babylonian (sic) and the inspiration for the later Egyptian work was assumed to be such examples. This idea is now completely dismissed.

${ }^{8}$ Petrie, Tell el Amarna, pl. XVIII, nos. 393-438. With the exception of the simpler designs as above, 416 etc.

${ }^{9}$ Hayes, Glazed Tiles from a Palace of Ramesses II, p. 1 for a history of discovery of source of tiles.

${ }^{10}$ Laon - 2 examples W $.4 .8 \mathrm{~cm}$, nos. 37.1547/1 \& 2C; Leicester City Museum, no. not known; Swansea EC515; Turin as above. Another group of example(s) now in Leiden are catalogued as from Qantir (?) no. VI.13 RMO Leiden F 1993/7.1-6, p. 330 in Giovetti and Picchi (eds.) Egitto: Splendore millenario. But these are misidentified - they must come from Tell el-Yahudiyeh (I owe thanks to Federico Poole for drawing this reference to my attention). And of course, much more extensive collections (containing the whole range of tile types) can be found in the Louvre, Paris; the British Museum and the Petrie Collection, London; the Fitzwilliam, Cambridge; Liverpool World Museum; and Berlin, Manchester, Sevres, etc.
${ }^{11}$ Fabretti et al., Regio Museo di Torino, II, no. 6824, p. 283.

${ }^{12}$ Vidua's list is transcribed in [Vidua], Documenti inediti, pp. 206-92.

${ }^{13}$ These lots of objects are briefly listed in Curto, Storia del Museo Egizio, pp. 96-106.

${ }^{14}$ Curto, Storia del Museo Egizio, p. 103, reference courtesy of Federico Poole.

${ }^{15}$ Federica Ugliano, personal communication, $16 / 1 / 2017$.

${ }^{16}$ Fabretti et al., Regio Museo di Torino, II, no. 7385, p. 337.

${ }^{17}$ Fabretti et al., Regio Museo di Torino, II.

${ }^{18}$ Hamza, ASAE 30 (1930), pp. 31-68, pls. I-IV; Hayes, Glazed Tiles from a Palace of Ramesses II, 1937.

${ }^{19}$ Hayes, The Scepter of Egypt, p. 367.

${ }^{20}$ Hamza, ASAE 30 (1930), p. 59; Hayes, Glazed Tiles from a Palace of Ramesses II, p.6.

${ }^{21}$ Hamza, ASAE 30 (1930), pp. 39-68, pls. 1-4; Rehren and Pusch, JEA 83 (1997), pp. 127-41; Pusch, ÄgLev 1 (1990), pp. 75-113; Pusch, ÄgLev 4 (1994), pp. 145-70; Rehren, Archaeometry 39 (1997), pp. 355-68; Rehren, and Pusch, Science 308 (2005), pp. 1756-759; Rehren, Archaeology International 9 (2005), pp. 40-42, DOI: https://ai-journal.com/articles/abstract/10.5334/ai.0911/.

${ }^{22}$ PM IV, pp. 56-57.

${ }^{23}$ Coulié and Filimonos-Tsopotou, Rhodes, Ialysos T. 43, nos. 18-14, pp. 182-83, identified as an Egyptian rosette disc from Tell el-Yahudiyeh by G. Pierrat-Bonnefois p. 89.

${ }^{24}$ Naville and Griffith, The Mound of the Jew, p. 1.

${ }^{25}$ Guichard, Niebuhr in Egypt, p. 152, quoting from Niebuhr's Travels, I, p. 100.

${ }^{26}$ Maspero, Manual of Egyptian Archaeology, p. 305.

${ }^{27}$ Linant, Memoires, p. 139: "Oniosa, Castra Judaeorum. [...] À 20 kilometres d'Heliopolis, au nord, on voit un grand monticule de decombres qui sont les restes d'une très grande ville : ce monticule se nomme Tel-Yeuhoud ou Monticule des Juifs."

${ }^{28}$ Linant, Memoires, p. 141: “On voit continuellement des quantités d'hommes piocher ces décombres, tamiser ce qu'ils en retirent et transporter ce terreau à dos d'ânes et de chameaux à grandes distances, comme d'ailleurs cela se pratique partout où se trouvent les restes d'une ancienne ville égyptienne."

${ }^{29}$ I owe this information about the documentation and history of the rosette tiles in the Louvre collections to the great kindness of my colleague Geneviève Pierrat-Bonnefois.

${ }^{30}$ For example AO 39807, AO 39834, AO 39836. A much later phenomenon includes an intriguing Neo-Assyrian glazed tile in BM from Layard's excavations of Esarhaddon's Palace at Nimrud, which (possibly!) shows Egyptian prisoners wearing feather headdresses, BM N 1036, 680-669 B.C.

${ }^{31}$ Delaporte in 1864: now Louvre E 3942 \& E 3943; Collection Rousset Bey in 1868: Louvre AO 39738 includes five examples E 5118, E 5118A, B, C, D. Later acquisitions are another eleven acquired in 1899 from Mr Morel (Mission Bénédite); another gift of five in 1901 by M. Grandidier; another four in 1938 Legs Curtis.

${ }^{32}$ Brugsch-Bey, in Maspero, RT, VIII, p. 1.

${ }^{33}$ Hayter Lewis, TSBA, VII, part 2. Material 
given by Rev. Greville Chester in 1871 to the British Museum and to the Victoria and Albert Museum, later transferred to the British Museum. A large series of rosettes and other faience decorative pieces was registered in 1871 (1871, 0619. 297 etc.), other groups were registered in 1873, 1874, 1876, and yet others acquired from the Victoria and Albert Museum in 1982, and elsewhere. As a result there are varied sequences in the EA numbers: nos. around EA12369, EA16298, EA69290-69400.

${ }^{34}$ Maspero, L’Archéologie égyptienne, pp. 257-58.

${ }^{35}$ Naville and Griffith, The Mound of the Jew, p. 5, and pp. 5-6 for a survey of previous work done on the mound.

${ }^{36}$ Petrie, Hyksos and Israelite Cities, p. 2, pl. XVI A.

${ }^{37}$ Naville and Griffith, The Mound of the Jew.

${ }^{38}$ Hayter Lewis, TSBA, p. 177.

${ }^{39}$ EA 49163 (1871, 0620.4). The inscription on its face is in a similar but not identical writing, and with different spelling “Tel el Yahoudeyeh”. Compare the spelling used by Hayter Lewis, TSBA $7-$ Tel el Yahoudeh with that used by Brugsch Bey, RT 8 (1886) - Tel el Yahoudi; Griffith, The Antiquities of Tell el Yahudiyeh - Tell el-Yahudiyeh; Petrie, Hyksos and Israelite Cities - Tell el Yehudiyeh; PM 1924 Tell el-Yahudiya.

${ }^{40}$ Brugsch-Bey, RT 8 (1886).

${ }^{41}$ The Louvre collection from Tell el-Yahudiyeh has a size range from smallest diam. $2.1 \mathrm{~cm}$ (with eight petals) e.g. E 10357, to largest diam. $11.9 \mathrm{~cm}$, (with ten petals) e.g. AO 39822 (4 e.g.s); The British Museum, Department of Ancient Egypt and Sudan has a size range from smallest $1.1 \mathrm{~cm}$, EA 16310 to largest diam. $8.8 \mathrm{~cm}$, EA 16151. The difference in the size ranges of these two collections must be due to the fact that they were collected from different parts of the palace building.

${ }^{42}$ Petrie, Hyksos and Israelite Cities, pl. XVI A.

${ }^{43}$ Hayes, Glazed Tiles from a Palace of Ramesses II, pl. XIII.

${ }^{44}$ Schiaparelli handwritten records in the Museo Egizio, Turin, by courtesy of Federico Poole.

${ }^{45}$ Petrie, Hyksos and Israelite Cities.

${ }^{46}$ Turin, Museo Egizio, S. 2762; Leospo in Donadoni Roveri (ed.), Dal Museo al Museo, no. 11, fig. 17, p. 173. See also D’Amicone, in Bresciani (ed.), Le vie del vetro, pp. 76-79.

${ }^{47}$ Lotus frieze, from Tel el-Yahudiyeh. See Hayter Lewis, in TSBA, pl. VI, 2; Brugsch Bey, in Maspero, RT, pl. VI, 2; Maspero, Manual of Egyptian Archaeology, fig. 268; Schlick-Nolte and von Droste zu Hülshoff, CAA, no. 53, pp. 104-05. For the Heliopolis example see Leospo, in Donadoni Roveri, Dal Museo al Museo, no. 11, fig. 17, p. 173. For Medinet Habu see Uvo Hölscher, Excavations, IV, pl. 37, f.

${ }^{48}$ Leospo in Donadoni Roveri (ed.), Dal Museo al Museo, no. 11, p. 173: "raw materials related to the manufacture of objects in frit, faience and glass, and associated with the same objects, above all amulets, decorative elements (sic), little vases, small sculpture, and funerary statues, indicating the presence of a temple workshop specialising in this type of production"; see also Sbriglio and Ugliano in Pinarello (ed.), Current Research in Egyptology 2014, pp. 278-93.
${ }^{49}$ Amongst this material were found two much smaller moulds for rosette attachments (Museo Egizio, Turin, S. 3361, S. 3362), very reminiscent of similar moulds from Qantir, (Hamza n. 49 below pl. IV A, second row third from left) the rosette impression measuring ca $1.5 \mathrm{~cm}$ diam. These are however, not the same as the moulds for the rosette tiles, and were intended for fabric or furniture ornaments.

${ }^{50}$ Federica Ugliano, personal communication, $1 / 16 / 2017$.

${ }^{51}$ Raue, Heliopolis und das Haus des Re, p. 375.

${ }^{52}$ Dietrich Raue, personal communication, 25/11/2016.

${ }^{53}$ Other material from Hamza's excavation in 1928 is now in the Cairo Museum, whilst recent campaigns carried out by the Pelizaeus Museum, Hildesheim have yielded more material of the same nature - i.e. waste material in dumps - not in primary contexts. Of great value will be analysis of this material evidence for faience production with new scientific methods.

${ }^{54}$ Hayes, Glazed Tiles from a Palace of Ramesses II, pl. XIII, b.

${ }^{55}$ Hamza, ASAE 30 (1930), pp. 31-68, pls. I-IV.

${ }^{56}$ Petrie, Nebesheh and Defenneh, p. 45; Hamza, ASAE 30 (1930), p. 33.

${ }^{57}$ Site of Piramesses. Work undertaken by Thilo Rehren and Edgar Pusch has now revealed enormous industrial-size establishments for the production of glass and metal, putting this identification beyond a doubt. For main summary see Rehren and Pusch, JEA 83 (1997), pp. 127-41.

${ }^{58}$ Hamza ASAE 30 (1930), p. 41.

${ }^{59}$ Hamza, ASAE 30 (1930), pp. 42, 45-63. See Nicholson and Peltenburg, in Nicholson and Shaw (eds.), Ancient Egyptian Materials and Technology, p. 184.

${ }^{60}$ Pusch, AeUL 1 (1990), pp. 75-113; Rehren and Pusch, AeUL 9 (1990), pp. 171-79; Rehren, Archaeology International, pp. 40-42.

${ }^{61}$ Pusch and Rehren, Hochtemperatur-Technologie in der Ramses-Stadt, map 01, p. 20.

${ }^{62}$ Hamza, ASAE 30 (1930), p. 45.

${ }^{63}$ Hayter Lewis, in TSBA, VII, 1882 pl. IV, 1, p. 182; Maspero, Manual of Egyptian Archaeology, pp. 304-06; Crowell, in Friedman (ed.), Gifts of the Nile, p. 197.

${ }^{64}$ Hayes, Glazed Tiles from a Palace of Ramesses II, pp. 11-21.

${ }^{65}$ See Hamza, ASAE 30 (1930), pl. 1 - Asiatic captive; Hayes, Glazed Tiles from a Palace of Ramesses II, fig. 1 - reconstruction of dais, pl. V - squatting lion.

${ }^{66}$ Metropolitan Museum, New York, nos. 35.1.19, 35.1.21, Purchase, Rogers Fund, Edward S. Harkness Gift and by exchange, Hayes, Glazed Tiles from a Palace of Ramesses II, pls. II-IV.

${ }^{67}$ Hayes, Glazed Tiles from a Palace of Ramesses II, p. 41b.

${ }^{68}$ Hayes, Glazed Tiles from a Palace of Ramesses II, pl. XIII, b.

${ }^{69}$ Hamza ASAE 30 (1930), pp. 39-41, and see his specific comments on previous pillaging.

${ }^{70}$ PM II, pp. 523-25, Palaces of Ramesses III, lists references to faience tiles with cartouches, royal figures, captives, rekhyt birds etc., but not subsidiary decoration like rosettes.

${ }^{71}$ Anthes, in Hölscher, The Excavations of Medinet Habu, 
IV, part 2 p. 46, pl. 37.k.

${ }^{72}$ Naville, The Mound of the Jew, p. 6.

${ }^{73}$ Griffith, The Antiquities of Tel el Yahoudiyeh, part 2 of Naville and Griffith, The Mound of the Jew, p. 41.

${ }^{74}$ Petrie, Hyksos and Israelite Cities, pl. XVI A.

${ }^{75}$ Hayter Lewis, in TSBA, VII, pl. IV,1.

${ }^{76}$ Crowell, in Friedman (ed.) Gifts of the Nile, p. 205, n. 258; Maspero, Manual of Egyptian Archaeology, p. 305 . On display in Room 44 of the Cairo Museum, cases 463 and 464.

${ }^{77}$ Cairo Museum. I am extremely grateful to Guy Lecuyot for this photograph and for permission to use it in this article.

${ }^{78} \mathrm{Cf}$. the structure published in a drawing by Hayter Lewis, TSBA, VII, pl. IV. Here Fig. 11.

${ }^{79}$ BM EA 38273 (1871, 0620.17) L. 27 cm x W. 19 cm. I wish to thank the Keeper of the Department of Ancient Egypt and Sudan, Neal Spencer, for permission to publish this object.

${ }^{80}$ Of interest to us is that the diameter of the rosette discs in the BM example diminishes very slightly from left to right. The discs measure $5.1 \mathrm{~cm}, 5.0 \mathrm{~cm}$, $4.8 \mathrm{~cm}$, and $4.6 \mathrm{~cm}$, although this is not noticeable to the naked eye. Does this imply an intentionally organised difference?

${ }^{81}$ Tell el-Amarna, and Medinet Habu might be of help in further study.

${ }^{82}$ Hamza, ASAE 30 (1930), p. 53, p. 58.

${ }^{83}$ Petrie, Tell el Amarna, pl. XIX, nos. 441 and 447 compare directly with Hamza, ASAE 30 (1930), pl. IV.A, third row.

${ }^{84}$ Anthes, in Hölscher, The Excavations of Medinet Habu, pl. 37, bottom left corner.

${ }^{85}$ Petrie, Tell el Amarna, pls. XVIII, XIX.

${ }^{86}$ Hamza, ASAE 30 (1930), pl. VI.A.

${ }^{87}$ Vandiver in Kaczmarczyk and Hedges, Ancient Egyptian Faience, pp, A 117-18.

${ }^{88}$ I owe this suggestion to Ignazio Echevercia, Conservation Technician at the Petrie Collection Museum, University College, London.

${ }^{89}$ Nicholson, in Wendrich (ed.), UCLA Encyclopedia of Egyptology, http://digital2.library.ucla.edu/viewFile.do? contentFileId=1697618.

${ }^{90}$ Hayes, Glazed Tiles from a Palace of Ramesses II, pp. 8-10. But he mentions only “application” of glazes, he has no knowledge of the alternative glazing techniques of "effervescence" and "cementation," now identified as the other important methods of causing creation of the glaze surface.

${ }^{91}$ Nicholson, in Wendrich (ed.), UCLA Encyclopedia of Egyptology, p. 5.

${ }^{92}$ Masson-Berghoff, in Villing et al., Naukratis, pp. 13, 15. https://webarchive.nationalarchives.gov. uk/20190801125425/https://www.britishmuseum. org/research/online_research_catalogues/ng/naukratis_greeks_in_egypt/material_culture_of_naukratis/ foundation_deposits.aspx.

${ }^{93}$ Rehren and Pusch, JEA 83 (1997), p. 140.

${ }^{94}$ Friedman, in Friedman (ed.), Gifts of the Nile; Bianchi, in Friedman (ed.), Gifts of the Nile, pp. 22-29; Patch, in Friedman (ed.), Gifts of the Nile, pp. 32-43.

\section{Bibliography}

Anthes, Rudolf, “Catalogue of Tiles and Other Inlays”, in: Uvo Hölscher, The Excavations of Medinet Habu, IV: The Mortuary Temple of Ramses III, pt. II (OIP 55), Chicago 1951, pp. 42-47.

Bianchi, Robert, "Symbols and Meanings", in: Florence Dunn Friedman (ed.), Gifts of the Nile: Ancient Egyptian Faience (catalogue of the exhibition, Cleveland Museum of Art; Museum of Art, Rhodes Island School of Design; Kimbell Art Museum), London 1998, pp. 22-29.

Brugsch-Bey, Emil, “On et Onion”, RT 8 (1886), pp. 1-9.

Coulié, Anne and Melina Filimonos-Tsopotou, Rhodes: une île grecque aux portes de l'Orient, Paris 2014.

Crowell, Brigit, "Rosettes", in: Florence Dunn Friedman (ed.), Gifts of the Nile: Ancient Egyptian Faience (catalogue of the exhibition, Cleveland Museum of Art; Museum of Art, Rhodes Island School of Design; Kimbell Art Museum), London 1998, pp. 197, 205.

Curto, Silvio, Storia del Museo Egizio di Torino, Torino 1976.

D’Amicone, Elvira, "Vetri di Deir el-Medina e 'sacra' in faience da Eliopoli nel Museo Egizio di Torino”, in: Edda Bresciani (ed.), Le vie del vetro: Egitto e Sudan. Convegno-mostra, Palazzo Lanfranchi, Pisa, 28 maggio-12 giugno 1988, Pisa 1988.

Fabretti, Ariodante, Francesco Rossi and Ridolfo V. Lanzone, Regio Museo di Torino: Antichità Egizie, II (Catalogo generale dei musei di antichità e degli oggetti d'arte raccolti nelle gallerie e biblioteche del regno, 1. Piemonte), Torino 1888.

Freed, Rita E., Yvonne Markowitz and Sue H. D'Auria (eds.), Pharaohs of the Sun: Akhenaten, Nefertiti, Tutankhamen, Boston 1999.

Friedman, Florence Dunn, "Faience: The Brilliance of Eternity”, in: Florence Dunn Friedman (ed.), Gifts of the Nile: Ancient Egyptian Faience (catalogue of the exhibition, Cleveland Museum of Art; Museum of Art, Rhodes Island School of Design; Kimbell Art Museum), London 1998, pp. 15-21.

Giovetti, Paola and Daniela Picchi (eds.), Egitto: Splendore millenario. La collezione di Leiden a Bologna, Ginevra-Milano 2015.

Griffith, Francis Ll., The Antiquities of Tell el Yahudiyeh and Miscellaneous Work in Lower Egypt During the Years 1887-1888 (EEF Memoir 7), London 1890.

Guichard, Roger H., Niebuhr in Egypt: European Science in a Biblical World, 2014.

Hamza, Mahmud, "Excavations of the Department of Antiquities at Qantir (Faqus District) (May 21st-July 7th, 1928)", ASAE 30 (1930), pp. 31-68.

Hayes, William C., Glazed Tiles from a Palace of Ramesses II at Kantir (The Metropolitan Museum of Art, Papers no. 3), New York 1937.

Hayes, William C., The Scepter of Egypt: A Background for the Study of the Egyptian Antiquities in the Metropolitan Museum of Art, II. The Hyksos Period and the New Kingdom (1675-1080 B.C.), New York 1978.

Hayter Lewis, Thomas, “Tel-el-Yahoudeh (The Mound of the Jew)”, TSBA 7 (1882), pp. 177-92.

Hepper, Nigel, Pharaoh's Flowers: The Botanical Treasures of Tutankhamun, London 1990. 
Uvo Hölscher, The Excavations of Medinet Habu, IV: The Mortuary Temple of Ramses III, pt. II (OIP 55), Chicago 1951.

Linant de Bellefonds, Louis M.A., Mémoires sur les principaux travaux d'utilité publique exécutés en Egypte depuis les temps de la plus haute antiquité jusqu'à nos jours, Paris 1872-1873.

Leospo, Enrichetta, "Lastre di decorazione parietale dalla cappella di Sepedhotep", in: Anna Maria Donadoni Roveri, Dal Museo al Museo: Passato e futuro del Museo Egizio di Torino, Torino 1989, p. 173.

Manniche, Lisa, Sacred Luxuries: Fragrance, Aromatherapy and Cosmetics in Ancient Egypt, London 1999.

Maspero, Gaston, L’archéologie égyptienne, Paris 1887.

Maspero, Gaston, Manual of Egyptian Archaeology and Guide to the Study of Antiquities in Egypt: For the Use of Students and Travellers, London 1914.

Masson-Berghoff, Aurélia, “Foundation Deposits”, in: Alexandra Villing, Marianne Bergeron, Giorgos Bourogiannis, Alan Johnston, François Leclère, Aurélia Masson and Ross Thomas, Naukratis: Greeks in Egypt. British Museum Online Research Catalogue, 2013; https://webarchive.nationalarchives.gov. uk/20190801125425/https://www.britishmuseum. org/research/online_research_catalogues/ng/naukratis_greeks_in_egypt/material_culture_of_naukratis/ foundation_deposits.aspx.

Naville, Edouard and Francis Ll. Griffith, The Mound of the Jew and the City of Onias, Belbeis, Samanood, Abusir, Tukh el Karmus, 1887: The Antiquities of Tell el Yahudiyeh, and Miscellaneous Work in Lower Egypt During the Years 1887-1888, London 1890.

Nicholson, Paul and Edgar Peltenburg, "Egyptian Faience", in: Paul Nicholson and Ian Shaw, Ancient Egyptian Materials and Technology, Cambridge 2000.

Nicholson, Paul, “Faience Technology”, in: Willeke Wendrich (ed.), UCLA Encyclopedia of Egyptology, Los Angeles, 2009; http://digital2.library.ucla.edu/viewFile.do? contentFileId=1697618.

Niebuhr, Carsten, Travels through Arabia and Other Countries in the East, I, Edinburgh 1792.

Patch, Diana Craig, "By Necessity or Design: Faience Use in Ancient Egypt" in: Florence Dunn Friedman (ed.), Gifts of the Nile: Ancient Egyptian Faience, pp. 32-43.

Petrie, Flinders W., Tanis, II, Nebesheh (Am) and Defenneh (Tahpanhes), London 1886.

Petrie, Flinders W., Tell el Amarna, London 1894

Petrie, Flinders W., Hyksos and Israelite Cities, London 1906.

PM II = Porter, Bertha and Rosalind L.B. Moss, Topographical Bibliography of Ancient Egyptian Hieroglyphic Texts, Relief and Paintings, II, Theban Temples, Oxford 1929.

PM IV = Porter, Bertha and Rosalind L.B. Moss,
Topographical Bibliography of Ancient Egyptian Hieroglyphic Texts, Relief and Paintings, IV, Lower and Middle Egypt, Oxford 1934.

Pusch, Edgar B., “Metallverarbeitende Werkstätten der frühen Ramessidenzeit in Qantir-Piramesses/Nord: ein Zwischenbericht”, ÄgLev 1 (1990), pp. 75-113.

Pusch, Edgar B., "Divergierende Verfahren der Metallverarbeitung in Theben und Qantir? Bemerkungen zu Konstruktion und Technik”, ÄgLev 4 (1994), pp.145-70.

Pusch, Edgar B. and Thilo Rehren, HochtemperaturTechnologie in der Ramses-Stadt: Rubinglas für den Pharao, Hildesheim 2007.

Raue, Dietrich, Heliopolis und das Haus des Re: eine Prosopographie und ein Toponym im Neuen Reich (ADAIK, Ägyptologische Reihe, 16), Berlin 1999.

Rehren, Thilo, "Ramesside Glass-Colouring Crucibles", Archaeometry 39 (1997), pp. 355-68.

Rehren, Thilo, “Red Glass for the Pharaoh”, Archaeology International 9 (2005), pp. 40-42. DOI: https://ai-journal.com/articles/abstract/10.5334/ai.0911/.

Rehren, Thilo and Edgar B. Pusch, "Glass and GlassMaking at Qantir-Piramesses and Beyond," AeUL 9 (1990), pp. 171-79.

Rehren, Thilo and Edgar B. Pusch, “New Kingdom Glass-Melting Crucibles from QantirPiramesses”, JEA 83 (1997), pp. 127-41.

Rehren, Thilo and Edgar B. Pusch, "Late Bronze Age Egyptian Glass production at Qantir/ Piramesses", Science 308 (2005), pp. 1756-759.

Saleh, Abdel-Aziz, Excavations at Heliopolis: Ancient Egyptian Ounû, I, Cairo 1981.

Sbriglio, Alice Maria and Federica Ugliano, "Re-Examining Heliopolis: Unpublished Archaeological Data from the Archives of Ernesto Schiaparelli and Missione Archeologica Italiana", in Massimiliano S. Pinarello (ed.): Current Research in Egyptology 2014: Proceedings of the Fifteenth Annual Symposium, Oxford 2015, pp. 278-93.

Schlick-Nolte, Birgit and Vera von Droste zu Hülshoff, CAA, Mainz-Rhein 1984.

Vandiver, Pamela, “The Manufacture of Faience”, in: Alexander Kaczmarczyk and Robert E.M. Hedges, Ancient Egyptian Faience: An Analytical Survey of Egyptian Faience from Predynastic to Roman Times, Warminster 1983.

[Vidua, Carlo], “Collezione Drovetti, a. 1822. Catalogue de la collect. d'antiq. de mons. le chev. Drovetti," in: Documenti inediti per servire alla storia dei Musei d'Italia pubblicati per cura del Ministero della Pubblica Istruzione, III, Firenze-Roma 1880.

Williams, Stuart, “Anthemis pseudocotula: The Mayweed/ Chamomile", Swansea Newsletter, Inscriptions 23 (2007), p. 4. 